NBER WORKING PAPER SERIES

\title{
ESTIMATING REAL PRODUCTION AND EXPENDITURES ACROSS NATIONS: A PROPOSAL FOR IMPROVING THE PENN WORLD TABLES
}

\author{
Robert C. Feenstra \\ Alan Heston \\ Marcel P. Timmer \\ Haiyan Deng \\ Working Paper 10866 \\ http://www.nber.org/papers/w10866
}

\author{
NATIONAL BUREAU OF ECONOMIC RESEARCH \\ 1050 Massachusetts Avenue \\ Cambridge, MA 02138 \\ October 2004
}

We thank Bettina Aten, Brian Easton, Erwin Diewert, Peter Neary, Prasada Rao, Marshall Reinsdorf, Bart van Ark and seminar participants at Dartmouth College, the NBER, Federal Reserve Bank of San Francisco and the IARIW meeting in Cork, Ireland for helpful comments, along with Edwin Stuivenwold and Gerard Ypma for exceptional research assistance. Financial support was provided by the National Science Foundation. The views expressed herein are those of the author(s) and not necessarily those of the National Bureau of Economic Research.

C2004 by Robert C. Feenstra, Alan Heston, Marcel P. Timmer, and Haiyan Deng. All rights reserved. Short sections of text, not to exceed two paragraphs, may be quoted without explicit permission provided that full credit, including $(\odot)$ notice, is given to the source. 
Estimating Real Production and Expenditures Across Nations: A Proposal for Improving the Penn World Tables

Robert C. Feenstra, Alan Heston, Marcel P. Timmer, and Haiyan Deng

NBER Working Paper No. 10866

October 2004

JEL No. F41, O47

\section{ABSTRACT}

In this paper we propose a new approach to international comparisons of real GDP measured from the output-side. The traditional Geary-Khamis system to measure real GDP from the expenditureside is modified to include differences in the terms of trade between countries. It is shown that this system has a strictly positive solution under mild assumptions. On the basis of a set of domestic final output, import and export prices and values for 14 European countries and the U.S. it is shown that differences between real GDP measured from the expenditure and output-side can be substantial, especially for small open economies.

Robert C. Feenstra

Department of Economics

University of California

Davis, CA 95616

and NBER

rcfeenstra@ucdavis.edu

Alan Heston

Department of Economics

University of Pennsylvania

Philadelphia, PA 19104

aheston@econ.upenn.edu
Marcel P. Timmer

Faculty of Economics

University of Gronigen

P.O. Box 800

9700 AV Gronigen

The Netherlands

m.p.timmer@eco.rug.nl

Haiyan Deng

The Conference Board

845 Third Avenue

New York, NY 10022

haiyan.deng@conference-board.org 


\section{Introduction}

From its inception, the Penn World Tables (PWT), building on the International Comparisons Program (ICP) of the United Nations, has sought to compare the standard of living of individuals in different countries. That is, the term "real GDP per capita" as reported in the PWT is intended to represent the ability to purchase goods and services by a representative agent in the economy. The same is true of benchmark comparisons as published by the United Nations, Eurostat or OECD. But this expenditure-side interpretation of real GDP is quite different from the uses to which benchmark ICP and PWT data are frequently applied, such as in the "millions" of growth regressions (Sala-i-Martin, 1997), where "real GDP" is intended to reflect the production-side of the economy. ${ }^{1}$

The goal of this paper is to carefully distinguish the production or output-side measure of real GDP, denoted real GDP $P^{o}$, from the expenditure-side measure, denoted real GDP. Real $\mathrm{GDP}^{\mathrm{o}}$ reflects the production possibilities of an economy, whereas real GDP $\mathrm{e}^{\mathrm{e}}$ measures real expenditures which includes an adjustment for the trade balance. ${ }^{2}$ The reason these concepts were not distinguished in the ICP and PWT is that these projects treat the net foreign balance in an unsatisfactory way. While there may have been some data justifications for that treatment in benchmark studies of the 1970s, this is no longer the case. The treatment of exports and imports proposed in this paper will not only remove the ambiguity presently surrounding real GDP ${ }^{\mathrm{e}}$ and real $\mathrm{GDP}^{\mathrm{o}}$ in the ICP and PWT, but provides a rich new international measure, namely the difference between them. Essentially, these two concepts differ by the terms of trade in the economy, i.e. the prices at which goods are exported and imported.

\footnotetext{
1 There are many other applications where expenditure-side real GDP is used when output-side real GDP is really needed. Recent examples are Bernard and Jones (1996), Jones and Hall (1999) and Acemoglu and Ventura (2002).

${ }^{2}$ Note that we do not deal with differences in nominal GDP which arise when measured from either the expenditure,
} 
In the first section of the paper we provide a brief background on how the ambiguous treatment of foreign trade arose during the development of the various benchmark studies and the extensions in PWT. In section 2, the distinction between real GDP on the output-side and expenditure-side is set out conceptually, followed by a discussion of how they can be separately measured in time series data. In order to incorporate these concepts into the PWT, however, we need to have a cross-country measure of their difference.

To achieve this, we propose a measure of the purchasing power parity for outputs ( $\mathrm{PPP}^{\mathrm{o}}$ ) rather than expenditures $\left(\mathrm{PPP}^{\mathrm{e}}\right)$. Currently the cornerstone of the ICP and PWT is the PPP for final expenditures $\left(\mathrm{PPP}^{\mathrm{e}}\right)$, used to deflate nominal national income to obtain real GDP. This is described in Section 3. If instead we want to deflate nominal GDP to obtain real $G D P^{\mathrm{o}}$, then we need to use $\mathrm{PPP}^{\mathrm{O}}$, which incorporates prices for exports and imports including both final goods and intermediate inputs. In section 4 we show how $\operatorname{PPP}^{\mathrm{o}}$ can be computed using the Geary (1958)-Khamis $(1970,1972)$ (GK) system, and further broken down into separate PPP's for final expenditures, exports and imports. It should be emphasized that by working at the level of entire economies, rather than sectors, some of the difficulties with measuring output-based PPP's are avoided. In particular, we find that while the international prices of intermediate inputs (from trade statistics) are used, the corresponding domestic prices of intermediates are not needed at all. In this sense, our use of trade data provides a short cut to obtain output-based deflators for the entire economy. ${ }^{3}$

\footnotetext{
income or output side. In the remainder of the paper we assume that nominal GDP is given.

3 The International Comparisons of Output and Productivity (ICOP) project at the University of Groningen constructs real GDP by sector from the output side using the industry-of-origin approach. This requires comparison of sectoral output prices across countries (see van Ark and Timmer, 2004, for example). Sectoral real output can be aggregated to obtain real output GDP, but his has only been done for a limited number of countries so far. The short-cut proposed here, which uses international rather than domestic prices of intermediates, is much easier to implement for a larger set of countries.
} 
In section 5, we provide an empirical application of our techniques. The data used for this illustration are from the 1996 and 1999 OECD benchmark comparison and trade data for 14 European countries plus the United States. It would be desirable to apply the methods to other benchmark comparisons and to time series as in PWT, but that is future work. It seems to us very useful to gain some quantitative insight into the importance of this change in method at an early stage so that if it is not second order effect, then international organizations can begin considering its adaptation.

It turns out that real $\mathrm{GDP}^{\mathrm{o}}$ differs significantly from real $\mathrm{GDP}^{\mathrm{e}}$ for a number of European countries. For example, Portugal and Greece face terms of trade that are below the average for countries in our sample, so that real $\mathrm{GDP}^{\mathrm{e}}$ is less than real $\mathrm{GDP}^{\circ}$, by $4 \%$ or more in 1996 and 1999. Ireland also has a low terms of trade in 1996, with real GDP ${ }^{\mathrm{e}}$ less than real GDP ${ }^{\mathrm{o}}$, but its export PPP grows rapidly over 1996-99 which substantially narrows the gap between these two GDP measures. Since real GDP ${ }^{\mathrm{e}}$ is close to that reported by the OECD, we are finding that countries with low terms of trade have higher real GDP when estimated from the output-side than currently reported: these countries are more productive than the existing cross-country real GDP figures suggest. This applies especially to Portugal, Greece, and Ireland, and to a lesser extent to Austria, Belgium, Italy, the Netherlands and Spain. Our results suggest that the difference between real GDP measured from the expenditure and output side diminishes when countries become richer, and their terms of trade improve. Germany and the U.K. are prominent examples of the reverse pattern, whereby they have higher than average terms of trade and therefore real GDP ${ }^{\mathrm{e}}$ exceeds real $\mathrm{GDP}^{\mathrm{o}}$. Directions for further research are given in section 6 , and include: extending the empirical results to more countries and years; correcting for the use of unit-values for exports and imports; and theoretical extensions to our results. 


\section{Present Practice}

When the International Comparison Program began in 1968 there was some experience with purchasing power comparisons, including the expenditure side efforts of Gilbert and Kravis (1954) for the OEEC, and several bilateral comparisons with the USSR for the Comecon countries, and the study of Paige and Bombach (1959). ${ }^{4}$ Paige and Bombach carried out a comparison from the output side between the U.S. and the U.K. in which they encountered a number of difficulties, one of which was the need for double deflation for purposes of comparing value-added across sectors. That was a formidable task at the time and has become easier only to the extent that data are more available. Further Paige and Bombach realized that to make full comparisons it was necessary to collect prices on both final and intermediate products. Comparisons from the expenditure side appeared to require much less in the way of price collection. Thus when the United Nations International Comparisons Project began in 1968 it endorsed comparisons from both the output and expenditure sides, but recognized that it would be easier to carry out expenditure side comparisons.

While the expenditure side comparison does appear much easier than output side of national accounts, this is in part because the net foreign balance was treated in an ad hoc fashion. In benchmark comparisons the practice in Eurostat and the OECD has been to value the net foreign balance at exchange rates. Unfortunately, use of the exchange rate of one country, a practice in the EU, is not base-country invariant. The present practice in PWT is to value the net foreign balance at the PPP for domestic absorption, which is simple and is base country invariant. In many discussions over the years, it was generally recognized that the appropriate way to value trade would be at export and import prices. But certainly in the early years of the

\footnotetext{
${ }^{4}$ Still earlier work had been carried out by Colin Clark (1940) who prepared PPP and real GDP comparisons for a wide variety of countries which he was to expand and improve in a 1957 edition.
} 
ICP this did not appear feasible from the standpoint of available data.

What was not really appreciated in these discussions is that valuing exports and imports at comparable prices was the only way to accurately compare the real output across countries, a central point of this paper. And once a comparison is made of real GDP on the output-side, it is possible to compare it to real GDP on the expenditure-side across countries. This difference turns out to not only be of analytic interest, but also to be a very revealing indicator of the extent to which the terms of trade differentially impact countries within any group like the OECD.

The distinction between real GDP on the output and expenditure-side can be illustrated by a simple diagram in a two-good economy, shown in Figure 1. We suppose that the production possibilities frontier shifts out due to technological change. At unchanged prices, production would increase from point A to point B. Suppose, however, that the relative price of good 1 falls due to its increased supply, so that the new prices are shown by the slope of the line $\mathrm{P}_{3} \mathrm{P}_{3}$. Production now occurs at $\mathrm{B}^{\prime}$ rather than $\mathrm{B}$. We have drawn the case where the budget lines $\mathrm{P}_{1} \mathrm{P}_{1}$ and $\mathrm{P}_{3} \mathrm{P}_{3}$ are both tangent to an indifference curve $\mathrm{U}$, at points $\mathrm{C}$ and $\mathrm{D}$, indicating that the utility of the representative consumer is unchanged.

In the case we have illustrated, the production points A and B' lie on the same ray from the origin so that the relative outputs of the two goods are unchanged. This means that any index of real output would be identical, and would simply equal $0 \mathrm{~B}^{\prime} / 0 \mathrm{~A}>1$, which is the proportional increase in both outputs. This is the increase in real $\mathrm{GDP}^{\circ}$ as measured on the output-side.

Now suppose we pose a different question, and ask what has happened to the welfare of the representative consumer, with indifference curve shown by $U$ in Figure 1. An exact measure of consumer welfare, or real GDP ${ }^{\mathrm{e}}$ measured on the expenditure-side, would be unchanged since the consumer has the same utility at the two prices. This occurs because there has been a fall in 
the price of the exportable good 1 . The change in real GDP $\mathrm{G}^{\mathrm{e}}$ could be measured by the change in nominal expenditure deflated by an exact consumer price index, constructed with the same prices as real $\mathrm{GDP}^{\mathrm{o}}$ but using consumption quantities rather than production quantities in the index.

This illustrates the most important difference between real $\mathrm{GDP}^{\mathrm{e}}$ and real $\mathrm{GDP}^{\mathrm{o}}$, i.e. the use of consumption quantities rather than production quantities in the index. The difference between these is exports and imports, of course, but for production quantities we also need to include the imports and exports of all intermediate inputs, as well as their prices. These data are not currently used by the ICP, which restricts its attention to final goods.

This distinction between real GDP on the expenditure and output-side is recognized by the United Nations 1993 System of National Accounts (SNA). The former is called real Gross Domestic Income (GDI), while the latter is real GDP. One definition ${ }^{5}$ of real GDI is:

$$
\text { Real GDI }=(\text { Nominal GDP }) /(\text { Domestic absorption price index }),
$$

as compared to,

$$
\text { Real GDP }=(\text { Nominal GDP }) /(\text { GDP price index })
$$

Nominal GDP, of course, is domestic absorption $(\mathrm{C}+\mathrm{I}+\mathrm{G})$ adjusted for the trade balance $(\mathrm{X}-\mathrm{M})$. The "domestic absorption price index" in (1) is constructed over the components of $(\mathrm{C}+\mathrm{I}+\mathrm{G})$. By excluding export and import prices from this price index, changes in the terms of trade (which affect nominal GDP) are then reflected in real GDI, as demonstrated by Diewert and Morrison (1986). An improvement in the terms of trade, for example, would cause real GDI to grow faster than real GDP. Kohli (2004) has shown that this pattern holds for Switzerland, due

\footnotetext{
5 See http://unstats.un.org/unsd/sna1993/introduction.asp, paragraph 16.154. The other definitions of real GDI depend on the deflator used for (X-M). Other than the domestic absorption price index, we might use the import price index, export price index, or an average of these, as recommended by Geary; see Neary (1997).
} 
to its terms of trade improvement. We shall avoid the term "real GDI," because it is suggestive of the income-approach to measuring GDP (through adding up the earnings of factors) which we do not use. Instead, we use real GDP $\mathrm{e}^{\mathrm{e}}$ to reflect the expenditure-side concept like (1). This is essentially the same as "real expenditure", except that by using nominal GDP rather than nominal expenditures in the numerator of (1) we are adjusting for the net foreign balance.

Now we come to the key question motivating this paper: which concept does the PWT use as "real GDP" - the output-side measure real GDP ${ }^{\circ}$, or the expenditure-side measure real $\mathrm{GDP}^{\mathrm{e}}$ ? It turns out that the answer is unclear: the ICP constructs real GDP ${ }^{\mathrm{e}}$ in benchmark years, but then to interpolate between these years, the PWT must reconcile these changes in real $\mathrm{GDP}^{\mathrm{e}}$ with the national accounts data reports on countries real GDP growth. Since national accounts real GDP growth is closer to real GDP ${ }^{\circ}$, which is being compared to benchmark estimates of real GDP ${ }^{\mathrm{e}}$, the distinction between these becomes lost in the reconciliation. ${ }^{6}$ In other words, the differences between real GDP ${ }^{\mathrm{e}}$ (using ICP data) and real GDP ${ }^{\mathrm{o}}$ (using national accounts data) is eliminated, and the year-to-year growth of real GDP from the national accounts is used to impute real GDP in the PWT for all years in-between the benchmark years. The fact that the distinction between real GDP $\mathrm{e}^{\mathrm{e}}$ and $\mathrm{GDP}^{\mathrm{o}}$ is not clearly made is a limitation of previous versions of the PWT that future revisions intend to improve upon. ${ }^{7}$

\footnotetext{
6 Real GDP in the national accounts always includes a measure of terms of trade losses or gains, although the deflator used might differ (see previous footnote). The process of reconciling the initial PWT estimates (in benchmark years) and the national accounts data for each country is described in Summers and Heston (1991, pp. 339-341).

7 For example the title of the Phase III report of the ICP was World Product and Income (Kravis, Heston and Summers, 1982). This clearly implied a treatment of GDP converted at PPPs of countries as interchangeable with what is termed output and expenditure in this paper. Further the provision of output per worker figures in PWT, though provided because users were taking per capita real GDP as a labor productivity measure, clearly implies that the real GDP number is an output measure.
} 


\section{Measurement of real GDP on the Expenditure Side}

Suppose there are $\mathrm{i}=1, \ldots, \mathrm{M}$ final goods, such as the categories of goods currently collected by the ICP, of which the first $\mathrm{M}_{0}$ are non-traded. These final goods may also be used as intermediate inputs, and there are another $\mathrm{i}=\mathrm{M}+1, \ldots, \mathrm{M}+\mathrm{N}$ goods that are exclusively intermediate inputs; for convenience we treat these all as traded internationally. To treat domestic demand, trade and production in a consistent framework, an input-output analysis must be used. In this framework the fundamental equality is between total demand and total supply of each good. For each country $\mathrm{j}=1, \ldots, \mathrm{C}$, denote final demand by $\mathrm{q}_{\mathrm{ij}}$, intermediate demand by $\mathrm{z}_{\mathrm{ij}}$, output by $\mathrm{y}_{\mathrm{ij}}$, exports by $\mathrm{x}_{\mathrm{ij}}$ and imports by $\mathrm{m}_{\mathrm{ij}}$, for $\mathrm{i}=1, \ldots, \mathrm{M}+\mathrm{N}$. We assume that all of these quantities are nonnegative, but many can be zero: in particular, the intermediate inputs $\mathrm{i}=$ $\mathrm{M}+1, \ldots, \mathrm{M}+\mathrm{N}$ have $\mathrm{q}_{\mathrm{ij}}=0$, and the non-traded goods $=1, \ldots, \mathrm{M}_{0}$ have $\mathrm{x}_{\mathrm{ij}}=\mathrm{m}_{\mathrm{ij}}=0$. Total demand in country $\mathrm{j}$ is given by $\mathrm{q}_{\mathrm{ij}}+\mathrm{x}_{\mathrm{ij}}+\mathrm{z}_{\mathrm{ij}}$, and total supply by $\mathrm{y}_{\mathrm{ij}}+\mathrm{m}_{\mathrm{ij}}$. Hence the equality between demand and supply is:

$$
\mathrm{q}_{\mathrm{ij}}+\mathrm{x}_{\mathrm{ij}}+\mathrm{z}_{\mathrm{ij}}=\mathrm{y}_{\mathrm{ij}}+\mathrm{m}_{\mathrm{ij}}, \mathrm{i}=1, \ldots, \mathrm{M}+\mathrm{N} .
$$

Re-arranging terms, we obtain:

$$
q_{i j}+x_{i j}-m_{i j}=y_{i j}-z_{i j}, \quad i=1, \ldots, M+N .
$$

where we refer to $y_{i j}-z_{i j}$ as "net output" of each good, i.e. gross output minus intermediate demand.

Multiplying by prices and summing over goods $\mathrm{i}=1, \ldots, \mathrm{M}+\mathrm{N}$, nominal GDP can be measured either from the expenditure side (left-hand side of (4)) or from the production side (right-hand side), where the units are the national currency. We presume that for a particular product, the prices of exports and imports can differ from domestic output and consumption. Such price differences always occur in practice, which is why we incorporate them here, without 
considering why the price differences arise. We distinguish the prices $\mathrm{p}_{\mathrm{ij}}>0$ for domestic output and consumption, used to multiply $\mathrm{q}_{\mathrm{ij}}, \mathrm{i}=1, \ldots, \mathrm{M}+\mathrm{N}$, from those for exports and imports, $\mathrm{p}_{\mathrm{ij}}^{\mathrm{x}}>0$ and $\mathrm{p}_{\mathrm{ij}}^{\mathrm{m}}>0$ respectively. ${ }^{8}$ Consistent with the System of National Accounts (SNA), the export prices are measured net of tariffs and freight, including any subsidy to the buyer but not to the seller, i.e. as the f.o.b. (freight on board) price in the exporting country. ${ }^{9}$ Likewise, the import prices are also measured net of tariffs. ${ }^{10}$

With these conventions for $\mathrm{p}_{\mathrm{ij}}^{\mathrm{m}}$ and $\mathrm{p}_{\mathrm{ij}}^{\mathrm{x}}$, let $\mathrm{X}_{\mathrm{j}}=\sum_{\mathrm{i}=\mathrm{M}_{0}+1}^{\mathrm{M}+\mathrm{N}} \mathrm{p}_{\mathrm{ij}}^{\mathrm{x}} \mathrm{x}_{\mathrm{ij}}$ and $\mathrm{M}_{\mathrm{j}}=\sum_{\mathrm{i}=\mathrm{M}_{0}+1}^{\mathrm{M}+\mathrm{N}} \mathrm{p}_{\mathrm{ij}}^{\mathrm{m}} \mathrm{m}_{\mathrm{ij}}$ denote the value of exports and imports at tariff-free prices, so that nominal GDP measured on the expenditure side is:

$$
\text { Nominal GDP } \mathrm{G}_{\mathrm{j}}^{\mathrm{e}} \equiv \sum_{\mathrm{i}=1}^{\mathrm{M}} \mathrm{p}_{\mathrm{ij}} \mathrm{q}_{\mathrm{ij}}+\left(\mathrm{X}_{\mathrm{j}}-\mathrm{M}_{\mathrm{j}}\right)
$$

Using (4), we can re-write (5) as:

$$
\begin{aligned}
\sum_{i=1}^{M} p_{i j} q_{i j}+\left(X_{j}-M_{j}\right) & =\sum_{i=1}^{M+N} p_{i j}\left[\left(y_{i j}-z_{i j}\right)-\left(x_{i j}-m_{i j}\right)\right]+\sum_{i=M_{0}+1}^{M+N}\left(p_{i j}^{x} x_{i j}-p_{i j}^{m} m_{i j}\right) \\
& =\sum_{i=1}^{M+N} p_{i j}\left(y_{i j}-z_{i j}\right)+\sum_{i=M_{0}+1}^{M+N}\left[\left(p_{i j}-p_{i j}^{m}\right) m_{i j}-\left(p_{i j}-p_{i j}^{x}\right) x_{i j}\right],
\end{aligned}
$$

where the first line is obtained by using $\mathrm{q}_{\mathrm{ij}}=\left(\mathrm{y}_{\mathrm{ij}}-\mathrm{z}_{\mathrm{ij}}\right)-\left(\mathrm{x}_{\mathrm{ij}}-\mathrm{m}_{\mathrm{ij}}\right)$ for the final goods $\mathrm{i}=1, \ldots, \mathrm{M}$, whereas the intermediates have $\mathrm{q}_{\mathrm{ij}}=0$, so that $\left[\left(\mathrm{y}_{\mathrm{ij}}-\mathrm{z}_{\mathrm{ij}}\right)-\left(\mathrm{x}_{\mathrm{ij}}-\mathrm{m}_{\mathrm{ij}}\right)\right]=0$ for $\mathrm{i}=\mathrm{M}+1, \ldots, \mathrm{M}+\mathrm{N}$.

\footnotetext{
8 In principle we should also distinguish producer from consumer prices, which can differ due to taxes and retail margins, but do not incorporate that distinction here.

9 See http://unstats.un.org/unsd/sna1993/introduction.asp, paragraphs 6.235, 6.237 and 15.35.

10 The SNA also recommends that import prices are also measured by the f.o.b. prices, though when this is not possible, then c.i.f. (cost, insurance, and freight) import prices can be used instead. We will use the convention that if the importing country hires the freight services of another country, then we use the c.i.f. import prices (importing both the good and the freight services), but if it uses its own carriers then the f.o.b. prices are used instead (since the freight charges are a part of domestic GDP).
} 
Then the second line follows because $x_{i j}=m_{i j}=0$ for the non-traded goods $i=1, \ldots, M_{0}$. We can interpret $\left(\mathrm{p}_{\mathrm{ij}}-\mathrm{p}_{\mathrm{ij}}^{\mathrm{m}}\right)$ as import tariffs (subsidies if negative), and $\left(\mathrm{p}_{\mathrm{ij}}-\mathrm{p}_{\mathrm{ij}}^{\mathrm{x}}\right)$ as exports subsidies (taxes if negative). So the final summation on the second line is interpreted as import revenue less export subsidies. ${ }^{11}$ Adding this to the value of net output $\sum_{\mathrm{i}=1}^{\mathrm{M}+\mathrm{N}} \mathrm{p}_{\mathrm{ij}}\left(\mathrm{y}_{\mathrm{ij}}-\mathrm{z}_{\mathrm{ij}}\right)$ as in (6) gives us nominal GDP measured on the production or output side: ${ }^{12}$

$$
\text { Nominal GDP }{ }_{j}^{o}=\sum_{i=1}^{M+N} p_{i j}\left(y_{i j}-z_{i j}\right)+\sum_{i=M_{0}+1}^{M+N}\left[\left(p_{i j}-p_{i j}^{m}\right) m_{i j}-\left(p_{i j}-p_{i j}^{x}\right) x_{i j}\right] \text {, }
$$

which clearly equals nominal GDP measured on the expenditure side, from (6).

The real counterpart to GDP measured on the expenditure-side in the PWT is obtained by using data for many countries, and computing average "reference price" for goods according to the Geary-Khamis (GK) system. The reference prices $\pi_{\mathrm{i}}^{\mathrm{e}}$ for final goods and the purchasing power parities $\mathrm{PPP}_{\mathrm{j}}^{\mathrm{e}}$ for each country are obtained from the simultaneous equations:

$$
\pi_{\mathrm{i}}^{\mathrm{e}}=\sum_{\mathrm{j}=1}^{\mathrm{C}}\left(\mathrm{p}_{\mathrm{ij}} / \mathrm{PPP}_{\mathrm{j}}^{\mathrm{e}}\right) \mathrm{q}_{\mathrm{ij}} / \sum_{\mathrm{j}=1}^{\mathrm{C}} \mathrm{q}_{\mathrm{ij}}, \quad \mathrm{i}=1, \ldots, \mathrm{M},
$$

and,

$$
\operatorname{PPP}_{\mathrm{j}}^{\mathrm{e}}=\sum_{\mathrm{i}=1}^{\mathrm{M}} \mathrm{p}_{\mathrm{ij}} \mathrm{q}_{\mathrm{ij}} / \sum_{\mathrm{i}=1}^{\mathrm{M}} \pi_{\mathrm{i}}^{\mathrm{e}} \mathrm{q}_{\mathrm{ij}}, \quad \mathrm{j}=1, \ldots, \mathrm{C} .
$$

In (8), the nominal prices $\mathrm{p}_{\mathrm{ij}}$ of final goods are deflated by the PPP exchange rate, and then averaged across countries. The exchange rates are obtained from (9), as the ratio of nominal to real final expenditure, where real expenditure is evaluated using the reference prices.

11 If the country is using its own transportation services for imports, so f.o.b. export prices are used for $\mathrm{p}_{\mathrm{ij}}^{\mathrm{m}}$, then what we are calling tariff revenue includes the transportation services, which are a part of GDP.

12 The SNA makes it clear that when measuring the trade balance in (5) at exporter prices, then tariffs less export subsidies need to be added to the value of net output as in (6) and (7) to obtain equality between GDP ${ }^{\mathrm{e}}$ and GDP . 
The system (8)-(9) are M+C equations, but are linearly dependent: by re-arranging (8) and summing over final goods, or by re-arranging (9) and summing over countries, we obtain:

$$
\sum_{i=1}^{M} \sum_{j=1}^{C} \pi_{i}^{e} q_{i j}=\sum_{i=1}^{M} \sum_{j=1}^{C} p_{i j} q_{i j} / \operatorname{PPP}_{j}^{e}
$$

so that world real expenditure at the reference prices $\pi_{\mathrm{i}}$ equals the sum of countries' expenditures deflated by the PPP exchange rates. This is the key aggregation property that the GK system is designed to satisfy. Because of this property, the system (8)-(9) has $M+C-1$ independent equations to determine $\mathrm{M}+\mathrm{C}$ unknowns, so a normalization must be chosen. We will use the normalization that world real expenditure equals the sum of countries' expenditures converted to dollars using the nominal exchange rates. ${ }^{13}$ Letting $E_{j}$ denote the local currency price of US\$ in each country $\mathrm{j}$, this normalization is:

$$
\sum_{i=1}^{M} \sum_{j=1}^{C} p_{i j} q_{i j} / P P P_{j}^{e}=\sum_{i=1}^{M} \sum_{j=1}^{C} p_{i j} q_{i j} / E_{j} .
$$

The fact that $\mathrm{q}_{\mathrm{ij}} \geq 0$ in (8)-(9), along with $\sum_{\mathrm{j}=1}^{\mathrm{N}} \mathrm{q}_{\mathrm{ij}}>0$, ensures that there is a positive solution for $\pi_{\mathrm{i}}^{\mathrm{e}}$ and $\mathrm{PPP}_{\mathrm{j}}^{\mathrm{e}}$ (Prasada Rao, 1971, Diewert, 1999). Then a normalization like (11) ensures that the solution in unique.

Subtracting from real expenditure the trade balance deflated by the PPP exchange rate, we obtain what is called real GDP in the PWT, and what we shall call real GDP ${ }^{\mathrm{e}}$ :

$$
\text { Real } \operatorname{GDP}_{j}^{\mathrm{e}} \equiv \sum_{\mathrm{i}=1}^{\mathrm{M}} \pi_{\mathrm{i}}^{\mathrm{e}} \mathrm{q}_{\mathrm{ij}}+\left(\mathrm{X}_{\mathrm{j}}-\mathrm{M}_{\mathrm{j}}\right) / \mathrm{PPP}_{\mathrm{j}}^{\mathrm{e}} \text {. }
$$

\footnotetext{
${ }^{13}$ Notice that this normalization differs from the one made in PWT 6.1 where the PPP for U.S. GDP was set as the numeraire. Actually, the procedure proposed here is equivalent to setting the PPP for 'world' GDP to unity.
} 
The idea of adjusting for the trade balance (evaluated at expenditure prices) is that we are interested in the purchasing power of the economy without borrowing from or lending to the future, i.e. using current resources. We can regard $\left(\mathrm{X}_{\mathrm{j}}-\mathrm{M}_{\mathrm{j}}\right)$ as an income transfer which is deflated by the PPP for domestic final goods, before evaluating real GDP on the expenditure side. This suggests an alternative normalization to $\operatorname{PPP}_{\mathrm{j}}^{\mathrm{e}}$ to that shown in (11), namely:

$$
\sum_{i=1}^{M} \sum_{j=1}^{C}\left[p_{i j} q_{i j}+\left(X_{j}-M_{j}\right)\right] / \operatorname{PPP}_{j}^{e}=\sum_{i=1}^{M} \sum_{j=1}^{C}\left[p_{i j} q_{i j}+\left(X_{j}-M_{j}\right)\right] / E_{j}
$$

In (13) we are specifying that world real GDP ${ }^{\mathrm{e}}$ equals world nominal GDP, where the latter is evaluated at the nominal exchange rates $\mathrm{E}_{\mathrm{j}}$. This normalization will be used for measured real $\mathrm{GDP}^{\mathrm{e}}$ in the remainder of the paper.

\section{Measurement of Real GDP on the Output Side}

In order to construct the output-side real GDP, it is necessary to deflate the net domestic output of goods, i.e. $\left(\mathrm{y}_{\mathrm{ij}}-\mathrm{z}_{\mathrm{ij}}\right)$ rather than final consumption of goods $\mathrm{q}_{\mathrm{ij}}$, i.e. using (7) rather than (5). In general, it is quite difficult to construct "reference prices" for all goods (final plus intermediate) across a range of countries, as needed for this type of calculation. This is the task that the International Comparisons of Output and Productivity (ICOP) project at the University of Groningen has undertaken for specific sectors and countries (see van Ark and Timmer, 2001), and it would be a Herculean task to do the same for the entire economies of multiple countries. As an alternative, we shall examine whether the data for final goods (already collected by the ICP and used by the PWT), combined with the additional data for exports and imports, are enough to give us a measure of output-side real GDP, called real GDP ${ }^{\mathrm{o}}$. 
We start with nominal $\mathrm{GDP}^{\mathrm{o}}$ defined in (7). Define real $\mathrm{GDP}^{\mathrm{o}}$ as the summation of real net output, exports and imports:

$$
\text { Real GDP } \operatorname{GP}_{\mathrm{j}}^{\mathrm{o}} \equiv \sum_{\mathrm{i}=1}^{\mathrm{M}+\mathrm{N}} \pi_{\mathrm{i}}^{\mathrm{o}}\left(\mathrm{y}_{\mathrm{ij}}-\mathrm{z}_{\mathrm{ij}}\right)+\sum_{\mathrm{i}=\mathrm{M}_{0}+1}^{\mathrm{M}+\mathrm{N}}\left[\left(\pi_{\mathrm{i}}^{\mathrm{o}}-\pi_{\mathrm{i}}^{\mathrm{m}}\right) \mathrm{m}_{\mathrm{ij}}-\left(\pi_{\mathrm{i}}^{\mathrm{o}}-\pi_{\mathrm{i}}^{\mathrm{x}}\right) \mathrm{x}_{\mathrm{ij}}\right] \text {. }
$$

Notice that on the right of (14) we include hypothetical tariff revenue less export subsidies measured at the reference prices $\pi_{\mathrm{i}}^{\mathrm{o}}, \pi_{\mathrm{i}}^{\mathrm{x}}$ and $\pi_{\mathrm{i}}^{\mathrm{m}}$, for net output, exports and imports, respectively. Consider the augmented-GK system to construct these reference prices:

$$
\begin{array}{ll}
\pi_{\mathrm{i}}^{\mathrm{o}}=\sum_{\mathrm{j}=1}^{\mathrm{C}}\left(\mathrm{p}_{\mathrm{ij}} / \mathrm{PPP}_{\mathrm{j}}^{\mathrm{o}}\right) \mathrm{q}_{\mathrm{ij}} / \sum_{\mathrm{j}=1}^{\mathrm{C}} \mathrm{q}_{\mathrm{ij}}, & \mathrm{i}=1, \ldots, \mathrm{M}, \\
\pi_{\mathrm{i}}^{\mathrm{x}}=\sum_{\mathrm{j}=1}^{\mathrm{C}}\left(\mathrm{p}_{\mathrm{ij}}^{\mathrm{x}} / \mathrm{PPP}_{\mathrm{j}}^{\mathrm{o}}\right) \mathrm{x}_{\mathrm{ij}} / \sum_{\mathrm{j}=1}^{\mathrm{C}} \mathrm{x}_{\mathrm{ij}}, & \mathrm{i}=\mathrm{M}_{0}+1, \ldots, \mathrm{M}+\mathrm{N}, \\
\pi_{\mathrm{i}}^{\mathrm{m}}=\sum_{\mathrm{j}=1}^{\mathrm{C}}\left(\mathrm{p}_{\mathrm{ij}}^{\mathrm{m}} / \mathrm{PPP}_{\mathrm{j}}^{\mathrm{o}}\right) \mathrm{m}_{\mathrm{ij}} / \sum_{\mathrm{j}=1}^{\mathrm{C}} \mathrm{m}_{\mathrm{ij}}, & \mathrm{i}=\mathrm{M}_{0}+1, \ldots, \mathrm{M}+\mathrm{N},
\end{array}
$$

and,

$$
\operatorname{PPP}_{\mathrm{j}}^{\mathrm{o}}=\frac{\text { Nominal GDP }_{\mathrm{o}}^{\mathrm{o}}}{\text { Real GDP }_{\mathrm{i}}^{\mathrm{O}}}, \mathrm{j}=1, \ldots, \mathrm{C} \text {. }
$$

In (15) we construct reference domestic prices for the final goods, and in (16) and (17) we construct reference prices for exports and imports. These are used to construct real $\mathrm{GDP}_{\mathrm{j}}^{\mathrm{o}}$ in (14), and purchasing-power-parity $\mathrm{PPP}_{\mathrm{j}}^{\mathrm{o}}$ is the ratio of nominal to real $\mathrm{GDP}_{\mathrm{j}}^{\mathrm{o}}$. In order for these definitions to make sense, we make the following assumption, already alluded to above:

\section{$\underline{\text { Assumption } 1}$}

Quantities are non-negative, $\mathrm{q}_{\mathrm{ij}}, \mathrm{x}_{\mathrm{ij}}, \mathrm{m}_{\mathrm{ij}} \geq 0$, with $\sum_{\mathrm{i}=1}^{\mathrm{M}} \mathrm{q}_{\mathrm{ij}}>0, \sum_{\mathrm{i}=\mathrm{M}_{0}+1}^{\mathrm{M}+\mathrm{N}} \mathrm{x}_{\mathrm{ij}}>0, \sum_{\mathrm{i}=\mathrm{M}_{0}+1}^{\mathrm{M}+\mathrm{N}} \mathrm{m}_{\mathrm{ij}}>0$. 
As it is written, however, the system (15)-(18) is incomplete because we have not yet specified the domestic reference prices of the intermediate inputs, i.e. $\pi_{\mathrm{i}}^{\mathrm{o}}$ for $\mathrm{i}=\mathrm{M}+1, \ldots, \mathrm{M}+\mathrm{N}$. These prices appear in real $\mathrm{GDP}_{\mathrm{j}}^{o}$ in (14). But fortunately, real $\mathrm{GDP}_{\mathrm{j}}^{\mathrm{o}}$ can be re-written to exclude these domestic reference prices for intermediate inputs:

$$
\begin{aligned}
& \text { Real GDP } \mathrm{GD}_{\mathrm{j}}^{\mathrm{o}}=\sum_{\mathrm{i}=1}^{\mathrm{M}+\mathrm{N}} \pi_{\mathrm{i}}^{\mathrm{o}}\left(\mathrm{y}_{\mathrm{ij}}-\mathrm{z}_{\mathrm{ij}}\right)+\sum_{\mathrm{i}=\mathrm{M}_{0}+1}^{\mathrm{M}+\mathrm{N}}\left[\left(\pi_{\mathrm{i}}^{\mathrm{o}}-\pi_{\mathrm{i}}^{\mathrm{m}}\right) \mathrm{m}_{\mathrm{ij}}-\left(\pi_{\mathrm{i}}^{\mathrm{o}}-\pi_{\mathrm{i}}^{\mathrm{x}}\right) \mathrm{x}_{\mathrm{ij}}\right] \\
& =\sum_{i=1}^{M} \pi_{i}^{o} q_{i j}+\sum_{i=M_{0}+1}^{M+N}\left(\pi_{i}^{x} x_{i j}-\pi_{i}^{m} m_{i j}\right) \text {, }
\end{aligned}
$$

which follows from (14) and (4), using $\left(y_{i j}-z_{i j}\right)=q_{i j}$ for the non-traded final goods $i=1, \ldots, M_{0}$, while the intermediate inputs have $\mathrm{q}_{\mathrm{ij}}=0$ so that $\left(\mathrm{y}_{\mathrm{ij}}-\mathrm{z}_{\mathrm{ij}}\right)=\left(\mathrm{x}_{\mathrm{ij}}-\mathrm{m}_{\mathrm{ij}}\right)$ for $\mathrm{i}=\mathrm{M}+1, \ldots, \mathrm{M}+\mathrm{N}$. Therefore, to compute real $\mathrm{GDP}_{\mathrm{j}}^{\mathrm{o}}$ we do not need the domestic reference prices $\pi_{\mathrm{i}}^{\mathrm{o}}$ at all for the intermediate inputs! Also, the second line of (14') makes it clear that real $\mathrm{GDP}_{\mathrm{i}}^{\mathrm{o}}$ is evaluated using reference prices $\pi_{\mathrm{i}}^{\mathrm{x}}$ and $\pi_{\mathrm{i}}^{\mathrm{m}}$ for traded goods that do not include any import tariffs or subsidies to exporters. Using (14'), we can re-write $\mathrm{PPP}_{\mathrm{j}}^{\mathrm{o}}$ in (18) as,

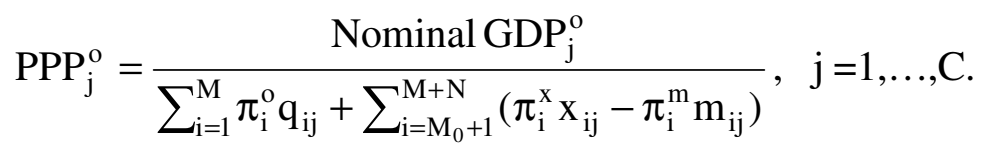

The system (15)-(17) and (19) has the same number of equations as unknowns. It can be confirmed that the equations are linearly dependent, in the sense that summing (15)-(17) or alternatively (19), we obtain:

$$
\sum_{j=1}^{C}\left(\sum_{i=1}^{M} \pi_{i}^{o} q_{i j}+\sum_{i=M_{0}+1}^{M+N}\left(\pi_{i}^{x} x_{i j}-\pi_{i}^{m} m_{i j}\right)\right)=\sum_{j=1}^{C}\left(\sum_{i=1}^{M} p_{i j} q_{i j}+\left(X_{j}-M_{j}\right)\right) / P P P_{j}^{o} .
$$


Thus, one normalization is needed, and we will specify that world real GDP deflated by the output-based $\mathrm{PPP}_{\mathrm{j}}^{\mathrm{o}}$ equals world GDP evaluated with the nominal exchange rates.

$$
\sum_{i=1}^{M} \sum_{j=1}^{C}\left[p_{i j} q_{i j}+\left(X_{j}-M_{j}\right)\right] / P P P_{j}^{o}=\sum_{i=1}^{M} \sum_{j=1}^{C}\left[p_{i j} q_{i j}+\left(X_{j}-M_{j}\right)\right] / E_{j}
$$

From the normalizations in (13) and (21), world real GDP evaluated on the expenditure-side will equal world real GDP evaluated on the output-side.

Summing up, we have shown that the augmented-GK system (15)-(17), (19) and (21) can be used to obtain a cross-country measure of the GDP price deflator from the output-side, which is $\mathrm{PPP}_{\mathrm{j}}^{\mathrm{o}}$. We have therefore achieved our goal of demonstrating that final goods data, in conjunction with export or import data, can be used to construct real $\mathrm{GDP}^{\mathrm{o}}$ on the output side. However, it remains to be shown that this system has a solution. This task is complicated by the fact that real $\mathrm{GDP}_{\mathrm{j}}^{\mathrm{o}}$, appearing in (14') and the denominator of (19), is not guaranteed to be positive for all possible reference prices. This can be ruled out by some additional assumptions, as follows.

First, define the budget shares for each final, export and import goods as:

$$
\theta_{\mathrm{ij}}^{\mathrm{v}} \equiv \mathrm{p}_{\mathrm{ij}}^{\mathrm{v}} \mathrm{v}_{\mathrm{ij}} / \text { Nominal GDP }_{\mathrm{j}}, \quad \mathrm{v}=\mathrm{q}, \mathrm{x}, \mathrm{m},
$$

where $\mathrm{i}=1, \ldots, \mathrm{M}$ for $\mathrm{v}=\mathrm{q} ; \mathrm{i}=\mathrm{M}_{0}+1, \ldots, \mathrm{M}+\mathrm{N}$ for $\mathrm{v}=\mathrm{x}, \mathrm{m}$; and $\mathrm{j}=1, \ldots, \mathrm{C}$. Notice that these budget shares are measured relative to nominal GDP. In addition, define the market shares for each good as:

$$
\mu_{\mathrm{ij}}^{\mathrm{v}} \equiv \mathrm{v}_{\mathrm{ij}} / \sum_{\mathrm{k}=1}^{\mathrm{C}} \mathrm{v}_{\mathrm{ik}}, \quad \mathrm{v}=\mathrm{q}, \mathrm{x}, \mathrm{m}
$$


where $\mathrm{i}=1, \ldots, \mathrm{M}$ for $\mathrm{v}=\mathrm{q}$; and $\mathrm{i}=\mathrm{M}_{0}+1, \ldots, \mathrm{M}+\mathrm{N}$ for $\mathrm{v}=\mathrm{x}, \mathrm{m}$. The market shares are measured relative to the world quantity of final demand, exports or imports for each good. Denote the column vectors of budget and market shares by $\theta_{j}^{\mathrm{v}}$ and $\mu_{\mathrm{j}}^{\mathrm{v}}$ for $\mathrm{v}=\mathrm{q}, \mathrm{x}, \mathrm{m}$ and country $\mathrm{j}$. Then our second assumption is:

\section{Assumption 2}

For all countries $\mathrm{j}, \mathrm{k}=1, \ldots, \mathrm{C}$, we have: $\mathrm{w}_{\mathrm{jk}} \equiv \theta_{\mathrm{j}}^{\mathrm{q}} \mu_{\mathrm{k}}^{\mathrm{q}}+\theta_{\mathrm{j}}^{\mathrm{x}} \mu_{\mathrm{k}}^{\mathrm{x}}-\theta_{\mathrm{j}}^{\mathrm{m}} \mu_{\mathrm{k}}^{\mathrm{m}}>0$.

Clearly, this assumption limits the size of the import shares $\theta_{\mathrm{ij}}^{\mathrm{m}}$ and $\mu_{\mathrm{ij}}^{\mathrm{m}}$. It is appropriate to think of $\mathrm{w}_{\mathrm{jk}}$ as "weights" because it is readily shown that $\sum_{\mathrm{k}=1}^{\mathrm{C}} \mathrm{w}_{\mathrm{jk}}=1$. While is it easy to construct examples where Assumption 2 is violated for some countries $\mathrm{j}$ and $\mathrm{k}$, it is also true that for "reasonable" values of the import budget and market shares, Assumption 2 can hold. (In fact, it will hold for the U.S. and European countries in our sample). Given this, we have:

\section{Theorem}

Under Assumptions 1 and 2, the system (15)-(17) and (19) has a strictly positive solution for $\pi_{\mathrm{i}}^{\mathrm{o}}, \pi_{\mathrm{i}}^{\mathrm{x}}, \pi_{\mathrm{i}}^{\mathrm{m}}$, real GDP $\mathrm{o}$ and $\mathrm{PPP}_{\mathrm{j}}^{\mathrm{o}}$.

It is worth emphasizing that Assumption 2 is a sufficient condition to obtain this result, but is not necessary. In particular, we show in the Appendix that the vector of real GDP ${ }_{j}^{o}$ across countries is a row eigenvector of the matrix $\mathrm{W}=\left[\mathrm{w}_{\mathrm{ij}}\right]$, corresponding to an eigenvalue of unity. Under Assumption 2, this is the Frobenius root of $\mathrm{W}$ and its corresponding eigenvector is strictly positive, so that real $\mathrm{GDP}_{j}^{\mathrm{o}}$ is strictly positive along with $\mathrm{PPP}_{\mathrm{j}}^{\mathrm{o}}$ and all the references prices, as stated in the Theorem. However, it is quite possible to obtain a strictly positive eigenvector and 
therefore a positive solution for real $\mathrm{GDP}_{\mathrm{j}}^{\mathrm{o}}$ even without having all the elements of $\mathrm{W}$ positive, and in this sense, Assumption 2 is sufficient but not necessary.

By rewriting real $\mathrm{GDP}_{\mathrm{j}}^{\mathrm{o}}$, it is possible to give a clear interpretation about the difference between it and real $\mathrm{GDP}_{\mathrm{j}}^{\mathrm{e}}$. Notice that real $\mathrm{GDP}_{\mathrm{j}}^{\mathrm{o}}$ in (14') can be decomposed as:

$$
\begin{aligned}
& \text { Real GDP } \mathrm{GD}_{\mathrm{j}}^{\mathrm{o}}= \\
& =\left(\frac{\sum_{\mathrm{i}=1}^{\mathrm{M}} \pi_{\mathrm{i}}^{\mathrm{o}} \mathrm{q}_{\mathrm{ij}}}{\sum_{\mathrm{i}=1}^{\mathrm{M}} \mathrm{p}_{\mathrm{ij}} \mathrm{q}_{\mathrm{ij}}}\right) \sum_{\mathrm{i}=1}^{\mathrm{M}} \mathrm{p}_{\mathrm{ij}} \mathrm{q}_{\mathrm{ij}}+\left(\frac{\sum_{\mathrm{i}=\mathrm{M}_{0}+1}^{\mathrm{M}+\mathrm{N}} \pi_{\mathrm{i}}^{\mathrm{x}} \mathrm{x}_{\mathrm{ij}}}{\sum_{\mathrm{i}=\mathrm{M}_{0}+1}^{\mathrm{M}+\mathrm{N}} \mathrm{p}_{\mathrm{ij}}^{\mathrm{x}} \mathrm{x}_{\mathrm{ij}}}\right) \mathrm{X}_{\mathrm{j}}+\left(\frac{\sum_{\mathrm{i}=\mathrm{M}_{0}+1}^{\mathrm{M}+\mathrm{N}} \pi_{\mathrm{i}}^{\mathrm{m}} \mathrm{m}_{\mathrm{ij}}}{\sum_{\mathrm{i}=\mathrm{M}_{0}+1}^{\mathrm{M}+\mathrm{N}} \mathrm{p}_{\mathrm{ij}}^{\mathrm{m}} \mathrm{m}_{\mathrm{ij}}}\right) \mathrm{M}_{\mathrm{j}} .
\end{aligned}
$$

W can define the three ratios appearing in (24) as the inverse of the PPP's for final expenditure, exports and imports:

$$
\operatorname{PPP}_{j}^{\mathrm{q}} \equiv\left(\frac{\sum_{\mathrm{i}=1}^{\mathrm{M}} \mathrm{p}_{\mathrm{ij}} \mathrm{q}_{\mathrm{ij}}}{\sum_{\mathrm{i}=1}^{\mathrm{M}} \pi_{\mathrm{i}}^{\mathrm{o}} \mathrm{q}_{\mathrm{ij}}}\right), \quad \operatorname{PPP}_{\mathrm{j}}^{\mathrm{x}} \equiv\left(\frac{\sum_{\mathrm{i}=\mathrm{M}_{0}+1}^{\mathrm{M}+\mathrm{N}} \mathrm{p}_{\mathrm{ij}}^{\mathrm{x}} \mathrm{x}_{\mathrm{ij}}}{\sum_{\mathrm{i}=\mathrm{M}_{0}+1}^{\mathrm{M}+\mathrm{N}} \pi_{\mathrm{i}}^{\mathrm{x}} \mathrm{x}_{\mathrm{ij}}}\right), \quad \operatorname{PPP}_{\mathrm{j}}^{\mathrm{m}} \equiv\left(\frac{\sum_{\mathrm{i}=\mathrm{M}_{0}+1}^{\mathrm{M}} \mathrm{p}_{\mathrm{ij}}^{\mathrm{m}} \mathrm{m}_{\mathrm{ij}}}{\sum_{\mathrm{i}=\mathrm{M}_{0}+1}^{\mathrm{M}} \pi_{\mathrm{i}}^{\mathrm{m}} \mathrm{m}_{\mathrm{ij}}}\right) .
$$

Comparing (12) and (24), it is immediate that the difference between real GDP $\mathrm{j}_{\mathrm{j}}^{\mathrm{e}}$ and real $\mathrm{GDP}_{\mathrm{j}}^{\mathrm{o}}$ is due to the deflation of final expenditure, exports and imports:

$$
\begin{aligned}
& \text { Real GDP } \mathrm{GD}_{\mathrm{j}}^{\mathrm{e}}-\text { Real GDP } \mathrm{j} \\
& =\left(\frac{\mathrm{PPP}_{\mathrm{j}}^{\mathrm{q}}}{\operatorname{PPP}_{\mathrm{j}}^{\mathrm{e}}}-1\right)\left(\frac{\sum_{\mathrm{i}=1}^{\mathrm{M}} \mathrm{p}_{\mathrm{ij}} \mathrm{q}_{\mathrm{ij}}}{\mathrm{PPP}_{\mathrm{j}}^{\mathrm{q}}}\right)+\left(\frac{\mathrm{PPP}_{\mathrm{j}}^{\mathrm{x}}}{\operatorname{PPP}_{\mathrm{j}}^{\mathrm{e}}}-1\right)\left(\frac{\mathrm{X}_{\mathrm{j}}}{\operatorname{PPP}_{\mathrm{j}}^{\mathrm{x}}}\right)-\left(\frac{\mathrm{PPP}_{\mathrm{j}}^{\mathrm{m}}}{\operatorname{PPP}_{\mathrm{j}}^{\mathrm{e}}}-1\right)\left(\frac{\mathrm{M}_{\mathrm{j}}}{\mathrm{PPP}_{\mathrm{j}}^{\mathrm{m}}}\right) .
\end{aligned}
$$

We could hope that $\mathrm{PPP}_{\mathrm{j}}^{\mathrm{e}}$ and $\mathrm{PPP}_{\mathrm{j}}^{\mathrm{q}}$ are similar, since they are both computed from final expenditures, but with different reference prices. If these two deflators for final expenditure were equal, then either $\mathrm{PPP}_{\mathrm{j}}^{\mathrm{x}}>\mathrm{PPP}_{\mathrm{j}}^{\mathrm{e}}$ or $\mathrm{PPP}_{\mathrm{j}}^{\mathrm{m}}<\mathrm{PPP}_{\mathrm{j}}^{\mathrm{e}}$ is needed to have real $\mathrm{GDP}_{\mathrm{j}}^{\mathrm{e}}$ exceed 
real $\mathrm{GDP}_{\mathrm{j}}^{\mathrm{o}}$, and both inequalities holding is sufficient for this. To interpret these conditions, it is useful to first convert export and import prices to U.S. dollars using the nominal exchange rate. Then having export prices above their reference level and import prices below their reference level will contribute towards real $\mathrm{GDP}_{\mathrm{j}}^{\mathrm{e}}$ exceeding real $\mathrm{GDP}_{\mathrm{j}}^{\mathrm{o}}$. For example, proximity to markets that allow for higher export prices would work in this direction, but being distant from markets leading to high import prices would work in the opposite direction, raising $\mathrm{PPP}_{\mathrm{j}}^{\mathrm{m}}$ and tending to make real $\mathrm{GDP}_{\mathrm{j}}^{\mathrm{e}}$ less than real $\mathrm{GDP}_{\mathrm{j}}^{\mathrm{o}}$.

We conclude this section with two warnings. First, the difference between our crosscountry measure of real $\mathrm{GDP}_{\mathrm{j}}^{\mathrm{e}}$ and real $\mathrm{GDP}_{\mathrm{j}}^{\mathrm{o}}$ does not measure the gains from trade as compared to autarky. Second, it should also not be interpreted as the cost of protection in a country. Instead, the difference between real $\mathrm{GDP}_{j}^{\mathrm{e}}$ and real $\mathrm{GDP}_{\mathrm{j}}^{\mathrm{o}}$ is a measure of the gains from trade from having export or import prices that differ from their reference prices $\pi_{\mathrm{i}}^{\mathrm{x}}$ and $\pi_{i}^{m}$. Since $\pi_{i}^{\mathrm{x}}$ and $\pi_{\mathrm{i}}^{\mathrm{m}}$ are themselves averages of countries' actual export and import prices, it is impossible for all countries to be gaining (or losing) relative to these averages. What we can expect to find is that some countries - with higher-than-average exports prices or low import prices - will gain in the sense that real $\mathrm{GDP}_{j}^{\mathrm{e}}$ exceeds real $\mathrm{GDP}_{\mathrm{j}}^{\mathrm{o}}$, whereas other countries will have real $\mathrm{GDP}_{\mathrm{j}}^{\mathrm{e}}$ less than real $\mathrm{GDP}_{\mathrm{j}}^{\mathrm{o}}$ due to low export prices or high import prices.

The fact that the difference between real $\mathrm{GDP}_{j}^{\mathrm{e}}$ and real $\mathrm{GDP}_{\mathrm{j}}^{\mathrm{o}}$ does not measure the costs of protection in a country can be seen from a simple example. Suppose that the reference price vectors for final goods are equal, $\pi_{\mathrm{i}}^{\mathrm{e}}=\pi_{\mathrm{i}}^{\mathrm{o}}$, and furthermore, the traded goods reference 
prices are proportional to observed prices in country $\mathrm{j}, \pi_{\mathrm{i}}^{\mathrm{x}}=\pi_{\mathrm{i}}^{\mathrm{m}} \propto \mathrm{p}_{\mathrm{ij}}^{\mathrm{x}}=\mathrm{p}_{\mathrm{ij}}^{\mathrm{m}}$, at which trade is balanced. The example we have in mind is where the domestic reference prices $\pi_{\mathrm{i}}^{\mathrm{e}}=\pi_{\mathrm{i}}^{\mathrm{o}}$ reflect average import tariffs applied by most countries, but the international reference prices $\pi_{\mathrm{i}}^{\mathrm{x}}=\pi_{\mathrm{i}}^{\mathrm{m}}$ reflect tariff-free prices. Since trade is balanced at the international reference prices, it is immediate that real $\mathrm{GDP}_{\mathrm{j}}^{\mathrm{e}}$ in (12) equals real $\mathrm{GDP}_{\mathrm{j}}^{\mathrm{o}}$ in $\left(14^{\prime}\right)$, both of which measure the value of production or consumption at domestic reference prices.

This situation is illustrated in Figure 2 for the case where country $\mathrm{j}$ has a tariff on good 2, with production at $\mathrm{A}$ and consumption at $\mathrm{B}$. The world relative price of good 1 is shown by the slope by the line $\mathrm{P}_{1} \mathrm{AC}$, while the domestic relative price is shown by the slopes of $\mathrm{P}_{2} \mathrm{P}_{2}$ and $\mathrm{P}_{3} \mathrm{P}_{3}$. Suppose initially that country j's tariff on good 2 is also applied by all other countries, so the domestic reference prices are proportional to domestic prices, $\pi_{\mathrm{i}}^{\mathrm{e}}=\pi_{\mathrm{i}}^{\mathrm{o}} \propto \mathrm{p}_{\mathrm{ij}}$. Then real GDP $\mathrm{G}_{\mathrm{j}}^{\mathrm{e}}$ equal to real GDP ${ }_{j}^{o}$ would both be measured by the budget line $\mathrm{P}_{3} \mathrm{P}_{3}$, which takes domestic revenue of $\mathrm{P}_{2} \mathrm{P}_{2}$ and adds the tariff revenue. Alternatively, suppose that countries other than $\mathrm{j}$ are engaged in free trade, so domestic reference prices $\pi_{\mathrm{i}}^{\mathrm{e}}=\pi_{\mathrm{i}}^{\mathrm{o}}$ equal international reference prices $\pi_{\mathrm{i}}^{\mathrm{x}}=\pi_{\mathrm{i}}^{\mathrm{m}}$, while only country $\mathrm{j}$ has the tariff on good 2 . In that case real GDP $\mathrm{j}_{\mathrm{j}}^{\mathrm{e}}$ equals real $\mathrm{GDP}_{\mathrm{j}}^{\mathrm{o}}$ again, and would both be measured by the budget line $\mathrm{P}_{1} \mathrm{AC}$, which is the value of production or consumption at world prices.

We see from this example that real $\mathrm{GDP}^{\mathrm{e}}$ can equal real GDP ${ }^{\mathrm{o}}$ even when country j's tariffs range from positive (low gains from trade) to zero (highest gains) to negative (possible losses from trade if subsidies are high enough). This means that observed differences between real $\mathrm{GDP}^{\mathrm{e}}$ and real $\mathrm{GDP}^{\mathrm{o}}$ cannot be interpreted as either gains from trade or the costs of 
protection. The reason for that is that both real GDP $\mathrm{e}$ and real $\mathrm{GDP}^{\mathrm{o}}$ are "fixed weight" indexes, where the quantities do not respond at all to the reference prices. In contrast, Neary (2004) has developed a theoretical PPP index on the expenditure-side whose weights reflect optimal consumer purchases in response to reference prices. For example, with reference prices given by the slope of $\mathrm{P}_{1} \mathrm{AC}$ in Figure 2, then optimal consumption would be at $\mathrm{D}$, and real expenditure to achieve utility $\mathrm{U}_{\mathrm{j}}$ would be given by the budget line $\mathrm{P}_{4} \mathrm{D}$. It seems possible that a theoretical PPP index on the output-side could also be developed, so that optimal output would occur at B, and real output would be measured by the budget line $\mathrm{P}_{5} \mathrm{~B}$. In this case, real output exceeds real expenditure, and the difference between them reflects the cost of protection. Extending our definitions of PPP and real GDP on the output-side to allow quantities to respond to reference prices, as Neary (2004) does for the consumer, would potentially provide a measure of the costs of protection, but is beyond the scope of this paper. Instead, we turn next to an empirical application of our results.

\section{Application to Europe and the U.S.}

To illustrate our formulas, we use a dataset for trade in 1996 and 1999 for 14 European countries and the United States. The source for the European data is the Prodcom dataset of Eurostat. This database contains specific product data classified according the 8-digit PRODCOM product list. ${ }^{14}$ Using the value and quantity, we constructed unit-values for exports and imports. There are 4,560 products in total, but for many of these the unit-values are not available or they are not traded by the European nations. As a check on the unit-values, we corrected some obvious errors in the units of quantity and then removed outliers. Outliers were

\footnotetext{
${ }^{14}$ The headings of the PRODCOM list are derived from the Harmonized System or the Combined Nomenclature, which thus enables comparisons to be made between production statistics and foreign trade statistics.
} 
defined as those unit-values which are greater than twice or less than half as much as the European average unit-value. ${ }^{15}$ The resulting cleaned dataset has 3,240 products in 1999 , with an average of about 1,900 products exported by each country and 2,350 products imported. Another 200 agricultural products were added from FAO trade data.

For the United States, export and imports for 1996 and 1999 are available on the Harmonized System (HS) basis, as described in Feenstra, Romalis and Schott (2002). Using a concordance between the 8-digit Prodcom codes and the 6-digit Harmonized System (HS) classification, we converted the U.S. export and import data to the Prodcom codes. On the export side in 1999, 47\% of merchandise exports corresponded to a Prodcom code in the cleaned European dataset (the remaining trade was not exported by Europe or did not have adequate unitvalues there). Some of these products had differing units of measurement in the U.S. and Europe, so correcting for these we ended up with $42 \%$ of U.S. exports, where the unit-values in the U.S. and Europe could be compared. For imports in 1999, 55\% of merchandise imports corresponded to a Prodcom code in the cleaned European dataset, and after correcting for different units of measurement, we obtained $49 \%$ of U.S. imports. The United States exports somewhat more products than the average European country in this dataset, and imports about the same number of products. ${ }^{16}$

For $\mathrm{PPP}_{\mathrm{j}}^{\mathrm{e}}$ we make use of the parities for about 200 expenditure categories provided by the OECD , in 1996 and 1999. Specifically, we compute the "expenditure price levels" for each country, defined as:

15 We also experimented with the looser criterion that outliers have unit-values which are greater than five times or less than one-fifth as much as the European average. Using this looser criterion did not have much impact on the countries $\mathrm{PPP}^{\mathrm{o}}$ or real GDP ${ }^{\circ}$, except for the case of Ireland, as discussed in note 19.

16 We also excluded U.S. products where the unit-value for exports or imports was greater than twice or less than one-half the average European unit-value. Excluding these products for the U.S. has a very small effect on the PPP's for any of the countries. 


$$
\mathrm{PL}_{\mathrm{j}}^{\mathrm{e}} \equiv P P P_{j}^{\mathrm{e}} / \mathrm{E}_{\mathrm{j}}=\sum_{\mathrm{i}=1}^{\mathrm{M}}\left(\mathrm{p}_{\mathrm{ij}} / \mathrm{E}_{\mathrm{j}}\right) \mathrm{q}_{\mathrm{ij}} / \sum_{\mathrm{i}=1}^{\mathrm{M}} \pi_{\mathrm{i}}^{\mathrm{e}} \mathrm{q}_{\mathrm{ij}}
$$

where $E_{j}$ denotes the local currency price of US\$ in each country $j$. Unlike the PPP's, the price levels are unit free, and indicate how the nominal prices in each country (converted to dollars with the nominal exchange rate) compare to the reference prices (also in dollars). These price levels are reported in columns (1) and (2) of Table 1 for 1996 and 1999. Note that between these two years there was a depreciation of all European currencies against the dollar, except for the British pound, as reported in column (3). This change let to a substantial fall in the price levels for European countries when converted to US\$, or $\left(\mathrm{p}_{\mathrm{ij}} / \mathrm{E}_{\mathrm{j}}\right)$ in (27). This reflects the well-known observation that domestic prices do not change as rapidly as nominal exchange rates. ${ }^{17}$

In columns (4) and (5) of Table 1 we report the relative output price level $\mathrm{PL}_{\mathrm{j}}^{\mathrm{o}}$ for 1996 and 1999, computed as the output-based PPPs divided by the nominal exchange rate, or $\mathrm{PPP}_{\mathrm{j}}^{\mathrm{o}} / \mathrm{E}_{\mathrm{j}}$. Note that the normalization used in these columns is identical to that in columns (1) and (2), i.e. the value of real GDP among the 15 countries equals the nominal value of GDP in US\$. As can be shown from (13) and (21), this means that a weighted average of the price levels sums to unity. The variance in output price levels are slightly greater than that in expenditure price levels. As to be expected, output and expenditure price levels are close for big countries such as the U.S., U.K. and France. But in small open economies like the Netherlands and Ireland, differences are bigger.

In Tables 2 and 3 output price levels are decomposed for the years 1996 and 1999, respectively. They are decomposed into price levels for final goods, exports and imports, that is:

\footnotetext{
${ }^{17}$ The results are close to those found when using PWT 6.1 data, see Appendix Table 1. Differences are caused by the fact that PPPs in PWT are based on a much larger set of countries, including non-OECD, than used here.
} 


$$
\begin{aligned}
& \mathrm{PL}_{\mathrm{j}}^{\mathrm{q}} \equiv \operatorname{PPP}_{\mathrm{j}}^{\mathrm{q}} / \mathrm{E}_{\mathrm{j}}=\sum_{\mathrm{i}=1}^{\mathrm{M}}\left(\mathrm{p}_{\mathrm{ij}} / \mathrm{E}_{\mathrm{j}}\right) \mathrm{q}_{\mathrm{ij}} / \sum_{\mathrm{i}=1}^{\mathrm{M}} \pi_{\mathrm{i}}^{\mathrm{o}} \mathrm{q}_{\mathrm{ij}}, \\
& \mathrm{PL}_{\mathrm{j}}^{\mathrm{x}} \equiv \mathrm{PPP}_{\mathrm{j}}^{\mathrm{x}} / \mathrm{E}_{\mathrm{j}}=\sum_{\mathrm{i}=\mathrm{M}_{0}+1}^{\mathrm{M}}\left(\mathrm{p}_{\mathrm{ij}} / \mathrm{E}_{\mathrm{j}}\right) \mathrm{x}_{\mathrm{ij}} / \sum_{\mathrm{i}=1}^{\mathrm{M}} \pi_{\mathrm{i}}^{\mathrm{x}} \mathrm{x}_{\mathrm{ij}}, \\
& \mathrm{PL}_{\mathrm{j}}^{\mathrm{m}} \equiv \mathrm{PPP}_{\mathrm{j}}^{\mathrm{m}} / \mathrm{E}_{\mathrm{j}}=\sum_{\mathrm{i}=\mathrm{M}_{0}+1}^{\mathrm{M}}\left(\mathrm{p}_{\mathrm{ij}} / \mathrm{E}_{\mathrm{j}}\right) \mathrm{m}_{\mathrm{ij}} / \sum_{\mathrm{i}=1}^{\mathrm{M}} \pi_{\mathrm{i}}^{\mathrm{m}} \mathrm{m}_{\mathrm{ij}} .
\end{aligned}
$$

These price levels are reported in columns (1) to (3) The ratio of $\mathrm{PL}_{\mathrm{j}}^{\mathrm{x}} / \mathrm{PL}_{\mathrm{j}}^{\mathrm{m}}$ is reported as the terms of trade for each country in column (4):

$$
\mathrm{TOT}_{\mathrm{j}} \equiv \mathrm{PL}_{\mathrm{j}}^{\mathrm{x}} / \mathrm{PL}_{\mathrm{j}}^{\mathrm{m}}, \mathrm{j}=1, \ldots, \mathrm{N}
$$

Finally, in columns (5)-(7) we report real GDP ${ }^{\mathrm{e}}$, real GDP ${ }^{\circ}$, and nominal GDP measured in US\$ for each year.

A number of observations can be made. First, the output price levels for final goods in column (1) appear to be very close to the expenditure price levels given in Table 1, which is encouraging. It indicates that the use of a different set of reference prices for final goods does not influence the estimation of a PPP for final goods: $\operatorname{PPP}_{j}^{q}$ is almost equal to $\operatorname{PPP}_{j}^{e}$. The choice for output prices for final goods $\pi_{i}^{\mathrm{q}}$ or expenditure prices $\pi_{\mathrm{i}}^{\mathrm{e}}$, where the former is influenced indirectly by exports and imports via the simultaneous system (15)-(19) but the latter is not, is inconsequential.

Second, export price levels are highly correlated with the price levels of final goods, although the variance is much less. In 1996, the highest relative export price levels could be found in Sweden and Germany, while the lowest in Greece, Portugal and Spain. A similar pattern exists in 1999, except that now relative export prices in the U.S. are the highest of all. The latter finding is indicative of a lack of price response by U.S. exporters to the strengthening of the US\$ 
vis-à-vis the European currencies over the period from 1996 to 1999. Apart from exchange rates, other factors play an important role in explaining differences in export prices faced by various countries. It is well known that under imperfect competition, exporters can and do charge different prices in various destination markets (Knetter 1989, 1993). Such market segmentation can arise in response to changes in nominal exchange rates, or trade policies of the importer. In addition, it is becoming recognized that countries differ systematically in their qualities and bundles of export goods (Schott, 2004). This would also create differences in the relative unit-value of their exports. We would hope that the differences in export prices level shown in Table 2 and 3 are driven primarily by actual price rather than quality differences across countries, but have no way to control for this in our data (other than deleting outliers). We return to this topic in section 6 , where we discuss directions for further research.

Import price levels of countries shown in Table 2 and 3 are much closer to each other than either export or final goods prices - the standard deviation of import price levels are about one-half that for exports, and nearly one-third of that for final goods. This might be related to the fact that import baskets are much more similar across countries than export baskets. Dividing the export and import price level, we obtain the terms of trade for each country. These are especially low for countries like Greece, Portugal and Spain, indicating that their export PPPs are lower than their import PPPs, in contrast to Germany, U.K. and the U.S. who have the reverse pattern of high export PPPs. Generally, countries with higher per-capita GDP have higher terms of trade, as shown in Figure 3 where we graph the terms of trade in 1996 and 1999 against real $\mathrm{GDP}^{\mathrm{o}}$ in $1996 .^{18}$

18 Corresponding to the depreciation of their currencies, a number of European countries have a fall in their terms of trade between 1996 and 1999. This can be explained by export prices (in domestic currency) that were rising less than import prices, due to incomplete pass-through of exchange rates. This pattern does not hold for all countries, however. 
The pattern shown in Figure 3, whereby countries with higher per-capita GDP have higher terms of trade, carries over the to comparison of real $\mathrm{GDP}^{\mathrm{o}}$ and real GDP $\mathrm{C}^{\mathrm{e}}$. As shown in Figure 4, wealthier countries have real $\mathrm{GDP}^{\mathrm{e}}$ exceeding $\mathrm{GDP}^{\mathrm{o}}$, due to their high terms of trade. This pattern can also be seen from comparing columns (5) and (6) of Table 2 and 3. Portugal and Greece both have real GDP ${ }^{\mathrm{e}}$ levels that are lower than real GDP ${ }^{\circ}$, by at least $4 \%$ in 1996 and 1999. Ireland also had a low terms of trade in 1996, with real GDP ${ }^{\mathrm{e}}$ nearly $9 \%$ below real $\mathrm{GDP}^{\mathrm{O}}$, but its rapid growth in the export PPP narrowed the gap between these two GDP measures by 1999. ${ }^{19}$ Austria (in 1999), Belgium, the Netherlands (in 1999) and Spain are other examples of countries in which real GDP ${ }^{\mathrm{e}}$ is at least $2 \%$ lower than real GDP ${ }^{\mathrm{o}}$. Germany and the U.K. are prominent examples of the reverse pattern with real output GDP bigger than real expenditure GDP, due to relative advantageous terms of trade.

In general, one can say that countries with lower levels of GDP per capita (evaluated at either expenditure or output prices), also have disadvantageous terms of trade and hence higher differences between real GDP measured from the expenditure and output side. Stated another way, countries with lower level of GDP per capita are more productive when measured in terms of real $\mathrm{GDP}^{\mathrm{o}}$ than real GDP (since real GDP $^{\mathrm{e}}$ reflects both productivity and terms of trade). These findings have clear implications for much of the cross-country regression literature based on GDP measures at international prices from the PWT. For example, in the convergence

\footnotetext{
19 The change in the terms of trade for Ireland, and the reduction in its gap between real GDP ${ }^{\mathrm{e}}$ and real GDP ${ }^{\mathrm{o}}$, is sensitive to the outliers that are omitted from the dataset. We have excluded unit-values of export and imports that are more than twice or less than one-half the European average. If instead we use the looser criterion that unit-value are excluded if they are more than five times or less than one-fifth the European average, then the terms of trade improvement for Ireland becomes so large that it is implausible: the terms of trade improvement overwhelms the rise in real GDP ${ }^{\mathrm{e}}$, and means that real GDP $^{\mathrm{o}}$ actually falls between 1996 and 1999 . For this reason, we do not accept the results for Ireland obtained with the looser criterion for outliers in the trade unit-values.
} 
literature changes in GDP per capita are regressed on initial levels of GDP per capita. A standard result is that the conditional rate of convergence is about $2 \%$ per year. However, our results suggest that this rate might be overestimated. Cross-country differences in GDP per capita levels are less when measuring real GDP from the output side than from the expenditure side, as can be seen from the standard deviations reported in Tables 2 and 3. It is the former which is the right concept for convergence analysis, while the latter concept is actually being used in exercises based on PWT data.

In addition, our results suggest that the difference between real GDP measured from the expenditure and output side diminishes when countries become richer, as terms of trade are improving. This finding lends little support to the model by Acemoglu and Ventura (2002) in which convergence is being driven by declining export prices for countries that grow faster. They claim that specialization and trade introduce de facto diminishing returns: countries that accumulate capital faster than average experience a worsening of the terms of trade, depressing rates of return to capital and discouraging further accumulation. In contrast, our results suggest that countries which grow faster often enjoy improved terms of trade, hence international trade might be a driver of divergence in the world income distribution. However, before any conclusive statement can be made on this issue our approach need to be applied to a larger set of countries and a longer time period. This is one area for further research, as discussed in the next section.

\section{Conclusions and Directions for Further Research}

In this paper, it has been shown that there is a fundamental difference between real GDP measured from the output side or from the expenditure side in international comparisons. The difference between the two concepts is in the treatment of the terms of trade. Real GDP from the 
expenditure side represents the ability to purchase goods and services while real GDP from the output-side measures the production possibilities of the economy. It is the latter concept of real GDP which is of interest to many studies of growth and convergence in the world economy. However, available data from the OECD or the Penn World Tables is based on a mix of crosscountry expenditure-side measures of real GDP for benchmark years with national growth rates of real GDP based on output-side measures.

In this paper a clear-cut distinction between the two measures is made. It is shown that real GDP from the output-side can be measured using an augmented-Geary-Khamis system of international comparisons. The augmented-GK system includes reference price and PPPs not only for domestic final goods, but also for export and imports. It is shown that this expanded system has a strictly positive solution under mild assumptions. An application of the extended GK-system to 14 European countries and the U.S. shows that the quantitative differences between real GDP measured from the output- or expenditure-side are not of a second order. Real $\mathrm{GDP}^{\mathrm{e}}$ can overstate real $\mathrm{GDP}^{\mathrm{o}}$ by as much as $9 \%$, and the difference is especially large in small and open economies. It also appears that this difference diminishes when countries become richer, as terms of trade are higher in more advanced countries.

These findings can have serious implications for studies on growth and divergence in the world economy which currently are based on measures of GDP from the expenditure-side, but conceptually refer to measures of GDP from the output-side. However, before any conclusive statement can be made on this issue our approach need to be applied to a larger set of countries and a longer time period, which will be one topic of further research. Using international trade data from the United Nations which covers the period from 1962 to 2000, and a much wider set of countries, more will be known about the differences in the effects of terms of trade between 
countries and over time. Our goal for future research is to implement the approach in this paper to provide reliable measures of real GDP both from the output-side and expenditure-side in the new benchmark version of the Penn World Tables.

To achieve goal, we will need to address the problem of unit-values in exports and imports. It is impossible to avoid using these unit-values as measures of price (since no dataset exists for comparing actual trade prices across countries), but we should at least attempt to correct the unit-values for differences in quality across countries. To this end, we believe that a statistical approach will be required, and propose to adapt the "country-product-dummy" (CPD) methodology. Originally due to Summers (1973), the CPD methodology is a regression of prices on dummy variables for the product $\left(\pi_{i}\right)$ and the country $\left(\operatorname{PPP}_{j}\right)$ :

$$
\ln \mathrm{p}_{\mathrm{ij}}=\ln \pi_{\mathrm{i}}+\ln \mathrm{PPP}_{\mathrm{j}}+\varepsilon_{\mathrm{ij}}, \quad \mathrm{i}=1, \ldots, \mathrm{M}+\mathrm{N}, \mathrm{j}=1, \ldots, \mathrm{C}
$$

where $\varepsilon_{\mathrm{ij}}$ is a random error. Using different weights in this regression, we can obtain various formula for the reference prices $\pi_{\mathrm{i}}$ (Diewert, 2002, Prasada Rao, 2004). This regression methodology can be viewed as an alternative to the GK system to obtain reference prices. When the prices appearing in (32) are import or export unit-values, we can consider expanding the CPD method to control for quality differences. For example, if theory predicts that skilled-labor abundant countries produce high-quality goods, then labor endowment could be included in (32) as controls, with "true" prices measured as the predicted prices not including the impact of labor endowments. More generally, any variable affecting quality could be included in (32) as a control. This is analogous to conventional hedonic regressions, where the contribution of observed characteristics is subtracted from prices to obtain "quality-adjusted" prices. Ideally, we want to use such "quality-adjusted" prices to measure export and imports PPPs across countries, and therefore obtain real GDP on the output-side. 
A final area for future research, mentioned in section 4 , is to provide a firmer theoretical basis for the alternative measures of real GDP proposed here. Neary (2004) has shown how the GK system on the expenditure side can be reformulated to allow the consumer to optimally choose new quantities at the reference prices. ${ }^{20}$ In that way, he obtains PPPs that equal the ratio of consumer expenditure functions - at observed and reference prices. These expenditure-side PPPs can be interpreted as true cost-of-living indexes. Likewise, we would like to obtain an economic interpretation of the output-side real GDP proposed here, by allowing firms to respond to the reference prices. The output-side PPP would then reflect the value of production at two prices vectors, holding the production possibilities fixed. We expect that a comparison of such theoretical measures of expenditure and output-side real GDP would allow us to infer not only the impact of terms of trade, but also the costs of protection and other distortions, leading to differences between a country's production possibilities and consumer well-being.

20 Prasada Rao and Salazer-Carillo (1988) propose a similar extension of the GK system. 


\section{References}

Acemoglu, Daron and Jaume Ventura, 2002, “The World Income Distribution,” Quarterly Journal of Economics, 117, May, 659-694.

Bernard, Andrew and Charles Jones, 1996, “Comparing Apples to Oranges: Productivity Convergence and Measurement Across Industries and Countries," American Economic Review, December, 86, 1216-1238.

Clark, Colin, 1940, The Conditions of Economic Progress. London: Macmillan.

Diewert, W. Erwin, 1999, Axiomatic and Economic Approaches to International Comparisons," in Alan Heston and Robert E. Lipsey, eds., International And Interarea Comparisons of Income, Output and Prices, Studies in Income and Wealth vol. 61, Chicago: Univ. of Chicago and NBER, 13-87.

Diewert, W. Erwin and Catherine J. Morrison, 1986, “Adjusting Outputs and Productivity Indexes for Changes in the Terms of Trade," Economic Journal, 96, 659-679.

Diewert, Erwin, 2002, "Weighted Country Product Dummy Variable Regressions and Index Number Formula,” Discussion Paper no. 02-15, University of British Columbia.

Feenstra, Robert, John Romalis and Peter Schott, 2002, “U.S. Imports, Exports and Tariff Data, 1989-2001,” NBER Working Paper no. 9387.

Geary, R.C., 1958, “A Note on the Comparison of Exchange Rates and Purchasing Powers Between Countries," Journal of the Royal Statistical Society, series A, 121, 97-99.

Gilbert, Milton and Irving B. Kravis, 1954, An International Comparison of National Products and the Purchasing Power of Currencies: A Study of the United States, The United Kingdom, France, Germany and Italy. Paris: OEEC.

Jones, Charles I. and Robert E. Hall, 1999, "Why Do Some Countries Produce So Much More Output Per Worker Than Others?” Quarterly Journal of Economics, 116(1), 83-116.

Khamis, S., 1970, "Properties and Condition for the Existence of a New Class of Index Numbers," Sankhya, series B, 32, 81-98.

Khamis, S., 1972, "A new system of index numbers for national and international purposes," Journal of the Royal Statistical Society, series A, 135.

Knetter, Michael M., 1989, "Price Discrimination by U.S. and German Exports," American Economic Review, 79(1), March, 198-210. 
Knetter, Michael M., 1993, "International Comparisons of Pricing-to-Market Behavior," American Economic Review, 83(3), June, 473-486.

Kohli, Ulrich R., 2004, "Real GDP, Real Domestic Income, and Terms-of-Trade Changes," Journal of International Economics, 62(1), January, 83-106.

Kravis, Irving, Alan Heston and Robert Summers, 1982, World Product and Income. Baltimore: John Hopkins University Press.

Neary, Peter, 1997, “R.C. Geary's contributions to economic theory,” in D. Conniffe (ed.): Roy Geary, 1896-1983: Irish Statistician, Dublin: Oak Tree Press and ESRI, 93-118.

Neary, Peter, 2004, “True Multilateral Indexes for International Comparisons of Real Incomes," University College Dublin, American Economic Review, forthcoming.

Paige, D. and G. Bombach, 1959, A Comparison of National Output and Productivity in the United Kingdom and the United States. Paris: OEEC.

Prasada Rao, D.S., 1971, "Existence and Uniqueness of a New Class of Index Numbers," Sankhya, series B, 33, 341-354.

Prasada Rao, D.S., 1976, "Existence and Uniqueness of a System of Consistent Index Numbers," Economic Review, 27(2), 212-218.

Prasada Rao, D.S. and J. Salazer-Carillo, 1988, “A General Equilibrium Approach to the Construction of Multilateral Index Numbers,” in J. Salazer-Carillo and D.S. Prasada Rao, eds., World Comparison of Incomes, Prices and Product. Amsterdam: North-Holland, 19-37.

Prasada Rao, D.S., 2004, “The Country-Product-Dummy Method: A Stochastic Approach to the Computation fo Purchasing Power Parities in the ICP," presented at the SSHRC conference on Index Numbers and Productivity Measurement, Jun 30 - July 4, 2004, Vancouver, Canada.

Sala-i-Martin, Xavier X., 1997, “I Just Ran Two Million Regressions,” American Economic Review, Papers and Proceedings, May, 178-183.

Schott, Peter, 2004, “Across-Product versus Within-Product Specialization in International Trade," Quarterly Journal of Economics, May, 119(2), 647-678.

Summers, Robert and Alan Heston, 1991, "The Penn World Table (Mark 5): An Expanded Set of International Comparisons, 1950-1988," Quarterly Journal of Economics, May, 327-368. 
Summers, Robert, 1973, "International Comparisons with Incomplete Data," Review of Income and Wealth, 29(1), 1-16.

van Ark, Bart and Marcel Timmer, 2001, "PPPs and International Productivity Comparisons:

Bottlenecks and New Directions," paper for joint OECD-World Bank seminar on Purchasing Power Parities, 30 January - 2 February 2001, Washington, D.C. 


\section{$\underline{\text { Appendix }}$}

\section{Proof of Theorem:}

Denoting nominal GDP $\mathrm{P}_{\mathrm{j}}$ by $\mathrm{G}_{\mathrm{j}}$ and real $\mathrm{GDP}_{\mathrm{j}}^{\mathrm{o}}$ by $\mathrm{R}_{\mathrm{j}}^{\mathrm{o}}, \mathrm{j}=1, \ldots, \mathrm{C}$, we can substitute $\mathrm{PPP}_{\mathrm{j}}^{\mathrm{o}}=$ $R_{j}^{o} / G_{j}$ in (15)-(17) to obtain the reference prices,

$$
\begin{array}{ll}
\pi_{\mathrm{i}}^{\mathrm{o}}=\sum_{\mathrm{j}=1}^{\mathrm{C}} \mathrm{R}_{\mathrm{j}}^{\mathrm{o}} \theta_{\mathrm{ij}}^{\mathrm{q}} / \sum_{\mathrm{j}=1}^{\mathrm{C}} \mathrm{q}_{\mathrm{ij}}, & \mathrm{i}=1, \ldots, \mathrm{M}, \\
\pi_{\mathrm{i}}^{\mathrm{x}}=\sum_{\mathrm{j}=1}^{\mathrm{C}} \mathrm{R}_{\mathrm{j}}^{\mathrm{o}} \theta_{\mathrm{ij}}^{\mathrm{x}} / \sum_{\mathrm{j}=1}^{\mathrm{C}} \mathrm{x}_{\mathrm{ij}}, & \mathrm{i}=\mathrm{M}_{0}+1, \ldots, \mathrm{M}+\mathrm{N}, \\
\pi_{\mathrm{i}}^{\mathrm{m}}=\sum_{\mathrm{j}=1}^{\mathrm{C}} \mathrm{R}_{\mathrm{j}}^{\mathrm{o}} \theta_{\mathrm{ij}}^{\mathrm{m}} / \sum_{\mathrm{j}=1}^{\mathrm{C}} \mathrm{m}_{\mathrm{ij}}, & \mathrm{i}=\mathrm{M}_{0}+1, \ldots, \mathrm{M}+\mathrm{N},
\end{array}
$$

where we are making use of the definitions of budget shares in (22). Also using the market shares in (23), real $\mathrm{GDP}_{\mathrm{j}}^{\mathrm{o}}$ can be computed from (14') as,

$$
\begin{aligned}
\mathrm{R}_{\mathrm{k}}^{\mathrm{o}} & =\sum_{\mathrm{i}=1}^{\mathrm{M}} \pi_{\mathrm{i}}^{\mathrm{o}} \mathrm{q}_{\mathrm{ik}}+\sum_{\mathrm{i}=\mathrm{M}_{0}+1}^{\mathrm{M}+\mathrm{N}}\left(\pi_{\mathrm{i}}^{\mathrm{x}} \mathrm{x}_{\mathrm{ik}}-\pi_{\mathrm{i}}^{\mathrm{m}} \mathrm{m}_{\mathrm{ik}}\right) \\
& =\sum_{\mathrm{j}=1}^{\mathrm{C}} \sum_{\mathrm{i}=1}^{\mathrm{M}} \mathrm{R}_{\mathrm{j}}^{\mathrm{o}} \theta_{\mathrm{ij}}^{\mathrm{q}} \mu_{\mathrm{ik}}^{\mathrm{q}}+\sum_{\mathrm{j}=1}^{\mathrm{C}} \sum_{\mathrm{i}=\mathrm{M}_{0}+1}^{\mathrm{M}+\mathrm{N}} \mathrm{R}_{\mathrm{j}}^{\mathrm{o}}\left(\theta_{\mathrm{ij}}^{\mathrm{x}} \mu_{\mathrm{ik}}^{\mathrm{x}}-\theta_{\mathrm{ij}}^{\mathrm{m}} \mu_{\mathrm{ik}}^{\mathrm{m}}\right) \\
& =\sum_{\mathrm{j}=1}^{\mathrm{C}} \mathrm{R}_{\mathrm{j}}^{\mathrm{o}}\left(\theta_{\mathrm{j}}^{\mathrm{q}} \mu_{\mathrm{k}}^{\mathrm{q}}+\theta_{\mathrm{j}}^{\mathrm{x}} \mu_{\mathrm{k}}^{\mathrm{x}}-\theta_{\mathrm{j}}^{\mathrm{m}} \mu_{\mathrm{k}}^{\mathrm{m}}\right) .
\end{aligned}
$$

Define $\mathrm{w}_{\mathrm{jk}}$ as the term in parentheses in the last line of $(\mathrm{A} 4), \mathrm{W}=\left[\mathrm{w}_{\mathrm{jk}}\right]$ as the corresponding $\mathrm{CxC}$ matrix, and $\mathrm{R}^{\mathrm{o}}$ as the row vector $\left(\mathrm{R}_{1}^{\mathrm{o}}, \ldots, \mathrm{R}_{\mathrm{C}}^{\mathrm{o}}\right)$. Then (A4) can be re-written as:

$$
\mathrm{R}^{\mathrm{o}} \mathrm{W}=\mathrm{R}^{\mathrm{o}}
$$

so that the $\mathrm{R}^{\mathrm{o}}$ is a row eigenvector of the matrix $\mathrm{W}$.

It is readily checked that each row of $\mathrm{W}$ sums to unity: summing $\mathrm{w}_{\mathrm{jk}}$ over $\mathrm{k}=1, \ldots, \mathrm{C}$, the market shares $\mu_{\mathrm{k}}^{\mathrm{q}}, \mu_{\mathrm{k}}^{\mathrm{x}}$ and $\mu_{\mathrm{k}}^{\mathrm{m}}$ each sum to a column vector $(1, \ldots, 1)^{\prime}$, while post-multiplying 
the budget shares by this vector we obtain $\sum_{\mathrm{i}=1}^{\mathrm{M}} \theta_{\mathrm{ij}}^{\mathrm{q}}+\sum_{\mathrm{i}=\mathrm{M}_{0}+1}^{\mathrm{M}+\mathrm{N}}\left(\theta_{\mathrm{ij}}^{\mathrm{x}}-\theta_{\mathrm{ij}}^{\mathrm{m}}\right)=1$ for each $\mathrm{j}=1, \ldots, \mathrm{C}$, by definition of the budget shares in (22). Since W is strictly positive by Assumption 2, from the Frobenius theorem it has a positive eigenvalue that lies in-between the minimum and maximum of its row sums, and the associated row or column eigenvector is strictly positive. Since the row sums are all unity, then the Frobenius eigenvalue also equals one, and $\mathrm{R}^{\mathrm{o}}$ is the strictly positive row eigenvector corresponding to that eigenvalue. Using this in (15)-(18) we obtain strictly positive solutions for $\mathrm{PPP}_{\mathrm{j}}^{\mathrm{o}}$ and the reference prices. $\quad$ QED 


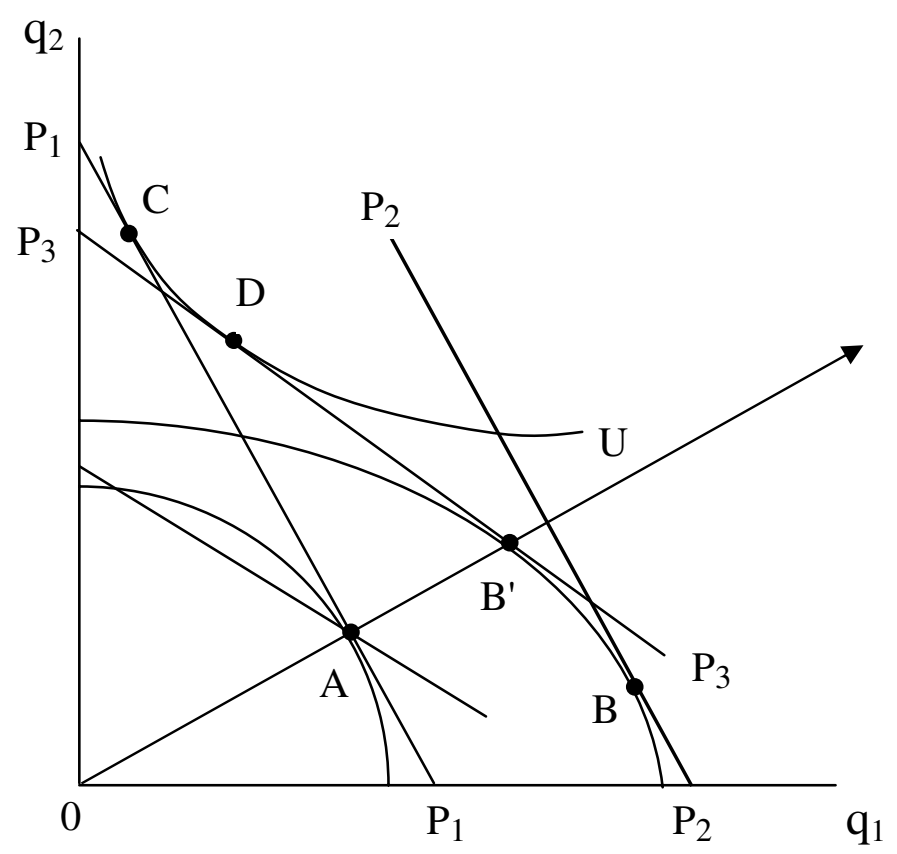

Figure 1

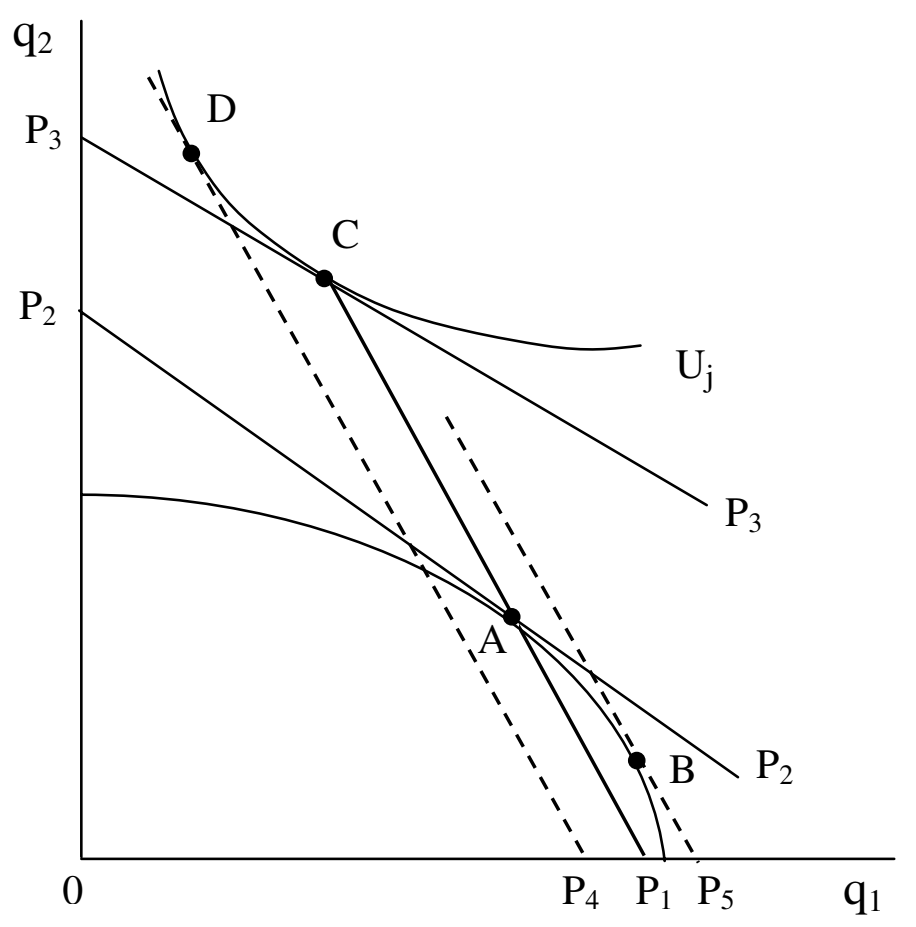

Figure 2 

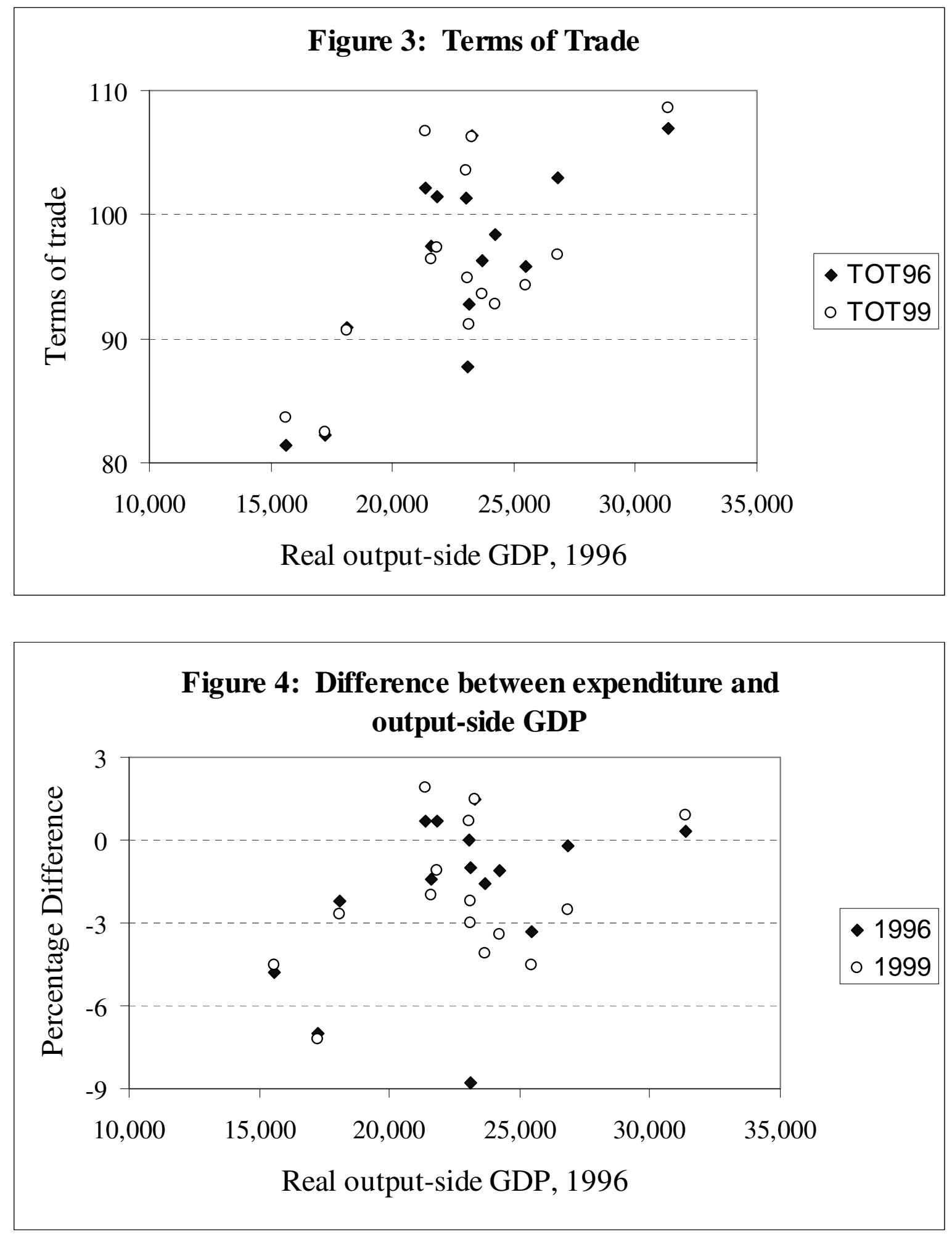
Table 1: Price Levels (PPP/nominal exchange rate)

\begin{tabular}{lccccc}
\hline & $\begin{array}{c}\text { Expenditure } \\
\text { Price Levels }\end{array}$ & $\begin{array}{c}\text { Deprecia- } \\
\text { tion of } \\
\text { Currency }\end{array}$ & $\begin{array}{c}\text { Output } \\
\text { Price Levels }\end{array}$ \\
& & & & & \\
& $\mathbf{1 9 9 6}$ & $\mathbf{1 9 9 9}$ & $\mathbf{1 9 9 6 - 9 9}$ & $\mathbf{1 9 9 6}$ & $\mathbf{1 9 9 9}$ \\
& $\mathbf{( 1 )}$ & $\mathbf{( 2 )}$ & $\mathbf{( 3 )}$ & $\mathbf{( 4 )}$ & $\mathbf{( 5 )}$ \\
Austria & 118.5 & 103.3 & -19.8 & 117.5 & 99.8 \\
Belgium & 106.9 & 98.7 & -20.1 & 103.4 & 94.2 \\
Denmark & 129.2 & 117.9 & -18.5 & 129.4 & 114.9 \\
Finland & 116.5 & 107.0 & -19.4 & 114.4 & 104.9 \\
France & 117.2 & 105.1 & -18.5 & 117.2 & 103.9 \\
Germany & 121.0 & 105.1 & -19.8 & 122.8 & 106.7 \\
Greece & 79.2 & 73.0 & -23.9 & 75.4 & 69.7 \\
Ireland & 95.9 & 101.1 & -16.7 & 87.6 & 98.1 \\
Italy & 93.0 & 86.1 & -16.3 & 91.6 & 84.2 \\
Netherlands & 106.7 & 95.2 & -20.4 & 104.3 & 91.2 \\
Portugal & 67.8 & 64.7 & -19.8 & 63.1 & 60.0 \\
Spain & 86.6 & 80.5 & -20.9 & 84.5 & 78.3 \\
Sweden & 132.3 & 116.0 & -20.9 & 131.6 & 116.8 \\
U.K & 94.0 & 108.7 & 3.6 & 94.3 & 110.7 \\
U.S. & 94.1 & 101.1 & 0.0 & 94.7 & 102.0 \\
Stan. Dev. & 18.7 & 15.2 & & 20.1 & 16.4 \\
\hline & & & & & \\
& & & & & \\
\hline
\end{tabular}

\section{Notes:}

Columns (1) and (2) are normalized so that the real value of GDP across countries equals the nominal value of GDP in US\$.

Column (3) from IMF, International Finance Statistics

Columns (4) and (5) have the same normalization as columns (1) and (2). 
Table 2: Price Levels, Real GDP ${ }^{\mathrm{e}}$ and Real GDP ${ }^{0}$ per-capita, 1996

\begin{tabular}{|c|c|c|c|c|c|c|c|c|}
\hline & \multicolumn{3}{|c|}{$\begin{array}{c}\text { Output-side } \\
\text { Price Levels, } 1996\end{array}$} & \multirow[b]{2}{*}{$\begin{array}{c}\text { Terms of } \\
\text { Trade }\end{array}$} & \multicolumn{4}{|c|}{ Real GDP $^{\mathrm{e}}$ and GDP $^{\mathrm{o}}$ per-capita } \\
\hline & $\begin{array}{l}\text { Final } \\
\text { Goods }\end{array}$ & Exports & Imports & & $\begin{array}{c}\text { Real } \\
\text { GDP }^{\mathrm{e}}\end{array}$ & $\begin{array}{c}\text { Real } \\
\text { GDP }^{\circ}\end{array}$ & $\begin{array}{l}\text { Diff } \\
(\%)\end{array}$ & $\begin{array}{l}\text { Nominal } \\
\text { \$GDP }\end{array}$ \\
\hline & (1) & (2) & (3) & (4) & (5) & (6) & (7) & (8) \\
\hline Austria & 118.2 & 113.4 & 115.3 & 98.4 & 23,984 & 24,246 & -1.1 & 28,621 \\
\hline Belgium & 106.7 & 100.9 & 105.3 & 95.8 & 24,637 & 25,479 & -3.3 & 26,485 \\
\hline Denmark & 129.0 & 113.5 & 110.2 & 103.0 & 26,788 & 26,829 & -0.2 & 34,755 \\
\hline Finland & 116.2 & 105.9 & 108.6 & 97.5 & 21,314 & 21,618 & -1.4 & 24,884 \\
\hline France & 117.0 & 106.1 & 104.7 & 101.4 & 21,996 & 21,835 & 0.7 & 25,962 \\
\hline Germany & 120.8 & 115.3 & 108.4 & 106.4 & 23,651 & 23,291 & 1.5 & 28,785 \\
\hline Greece & 79.0 & 81.0 & 99.5 & 81.4 & 14,857 & 15,598 & -4.8 & 11,871 \\
\hline Ireland & 95.7 & 90.2 & 102.8 & 87.7 & 21,071 & 23,117 & -8.8 & 20,330 \\
\hline Italy & 92.7 & 96.6 & 104.1 & 92.8 & 22,912 & 23,135 & -1.0 & 21,480 \\
\hline Netherlands & 106.5 & 101.9 & 105.8 & 96.3 & 23,307 & 23,678 & -1.6 & 25,034 \\
\hline Portugal & 67.6 & 85.5 & 104.0 & 82.2 & 16,014 & 17,227 & -7.0 & 10,978 \\
\hline Spain & 86.3 & 86.6 & 95.3 & 90.9 & 17,712 & 18,114 & -2.2 & 15,526 \\
\hline Sweden & 132.0 & 118.1 & 116.5 & 101.3 & 23,048 & 23,043 & 0.0 & 30,613 \\
\hline U.K & 93.8 & 100.6 & 98.5 & 102.1 & 21,515 & 21,358 & 0.7 & 20,249 \\
\hline U.S. & 94.1 & 100.6 & 94.1 & 106.9 & 31,476 & 31,379 & 0.3 & 29,442 \\
\hline Stan. Dev. & 18.7 & 11.5 & 6.5 & 8.0 & 4,102 & 3,867 & 3.0 & 18.7 \\
\hline
\end{tabular}

\section{Notes:}

Columns (1)-(3) decompose the price level taken from Table 1, column (6).

Column (4) equals (2)/(3).

Columns (5) and (6) are computed according to equations (12) and (14'), respectively.

Column (7) equals [(5)-(6)]/(5).

Column (8) reports nominal GDP per capita converted to US\$ with the nominal exchange rate.

The sums of real GDP ${ }^{\mathrm{e}}$, real $\mathrm{GDP}^{\mathrm{o}}$ and nominal \$GDP across countries are identical, by choice of normalization. 
Table 3: Price Levels, Real GDP ${ }^{\mathrm{e}}$ and Real GDP ${ }^{0}$ per-capita, 1999

\begin{tabular}{|c|c|c|c|c|c|c|c|c|}
\hline \multicolumn{5}{|c|}{$\begin{array}{c}\text { Output-side } \\
\text { Price Levels, } 1999\end{array}$} & \multicolumn{4}{|c|}{ Real GDP $^{\mathrm{e}}$ and GDP $^{\mathrm{o}}$ per-capita } \\
\hline & $\begin{array}{l}\text { Final } \\
\text { Goods }\end{array}$ & Exports & Imports & $\begin{array}{c}\text { Terms of } \\
\text { Trade }\end{array}$ & $\begin{array}{l}\text { Real } \\
\text { GDP }^{\mathrm{e}}\end{array}$ & $\begin{array}{r}\text { Real } \\
\text { GDP }^{\circ}\end{array}$ & $\begin{array}{l}\text { Diff } \\
(\%)\end{array}$ & $\begin{array}{l}\text { Nominal } \\
\text { \$GDP }\end{array}$ \\
\hline & (1) & (2) & (3) & (4) & (5) & (6) & (7) & (8) \\
\hline Austria & 103.2 & 100.7 & 108.5 & 92.8 & 25,147 & 26,039 & -3.4 & 25,976 \\
\hline Belgium & 98.4 & 94.5 & 100.2 & 94.3 & 24,930 & 26,110 & -4.5 & 24,606 \\
\hline Denmark & 117.5 & 98.4 & 101.7 & 96.7 & 27,604 & 28,305 & -2.5 & 32,534 \\
\hline Finland & 106.7 & 99.2 & 102.9 & 96.4 & 23,472 & 23,942 & -2.0 & 25,113 \\
\hline France & 104.8 & 94.7 & 97.3 & 97.4 & 22,846 & 23,107 & -1.1 & 24,004 \\
\hline Germany & 104.8 & 107.0 & 100.7 & 106.3 & 24,435 & 24,068 & 1.5 & 25,689 \\
\hline Greece & 72.9 & 73.0 & 87.3 & 83.6 & 16,369 & 17,138 & -4.5 & 11,942 \\
\hline Ireland & 100.9 & 107.0 & 112.8 & 94.9 & 25,217 & 25,993 & -3.0 & 25,498 \\
\hline Italy & 85.9 & 87.4 & 96.0 & 91.1 & 23,780 & 24,324 & -2.2 & 20,485 \\
\hline Netherlands & 94.9 & 89.9 & 96.0 & 93.6 & 26,503 & 27,648 & -4.1 & 25,218 \\
\hline Portugal & 64.6 & 79.4 & 96.2 & 82.5 & 18,000 & 19,399 & -7.2 & 11,645 \\
\hline Spain & 80.4 & 79.6 & 87.7 & 90.7 & 18,894 & 19,425 & -2.7 & 15,207 \\
\hline Sweden & 115.7 & 107.7 & 104.0 & 103.5 & 24,447 & 24,285 & 0.7 & 28,367 \\
\hline U.K & 108.4 & 103.1 & 96.6 & 106.7 & 22,607 & 22,194 & 1.9 & 24,577 \\
\hline U.S. & 101.1 & 107.7 & 99.2 & 108.6 & 33,574 & 33,280 & 0.9 & 33,951 \\
\hline Stan. Dev. & 15.2 & 11.3 & 6.7 & 7.8 & 4,128 & 3,983 & 2.6 & 6,488 \\
\hline
\end{tabular}

\section{Notes:}

Columns (1)-(3) decompose the price level taken from Table 1, column (6).

Column (4) equals (2)/(3).

Columns (5) and (6) are computed according to equations (12) and (14'), respectively.

Column (7) equals $[(5)-(6)] /(5)$.

Column (8) reports nominal GDP per capita converted to US\$ with the nominal exchange rate.

The sums of real GDP ${ }^{\mathrm{e}}$, real $\mathrm{GDP}^{\mathrm{o}}$ and nominal $\$$ GDP across countries are identical, by choice of normalization. 
Appendix Table 1: Alternative Expenditure Price Levels (PPP/nominal exchange rate)

\begin{tabular}{lcccc}
\hline & $\begin{array}{c}\text { Expenditure } \\
\text { Price Levels } \\
\text { based on OECD } \\
\text { data }\end{array}$ & $\begin{array}{c}\text { Expenditure } \\
\text { Price Levels, } \\
\text { based on PWT data }\end{array}$ \\
\hline Austria & $\mathbf{1 9 9 6}$ & $\mathbf{1 9 9 9}$ & $\mathbf{1 9 9 6}$ & $\mathbf{1 9 9 9}$ \\
Belgium & 118.5 & 103.3 & 122.9 & 107.6 \\
Denmark & 106.9 & 98.7 & 115.4 & 102.4 \\
Finland & 129.2 & 117.9 & 132.4 & 121.6 \\
France & 116.5 & 107.0 & 117.0 & 107.4 \\
Germany & 117.2 & 105.1 & 118.2 & 104.3 \\
Greece & 121.0 & 105.1 & 126.2 & 109.7 \\
Ireland & 79.2 & 73.0 & 85.3 & 80.1 \\
Italy & 95.9 & 101.1 & 99.9 & 101.8 \\
Netherlands & 93.0 & 86.1 & 96.1 & 90.1 \\
Portugal & 106.7 & 95.2 & 113.4 & 101.9 \\
Spain & 67.8 & 64.7 & 76.7 & 70.2 \\
Sweden & 86.6 & 80.5 & 91.5 & 82.7 \\
U.K & 132.3 & 116.0 & 130.0 & 115.6 \\
U.S. & 94.0 & 108.7 & 92.3 & 105.0 \\
Stan. Dev. & 94.1 & 101.1 & 91.6 & 99.1 \\
\hline & 18.7 & 15.2 & 17.7 & 13.8 \\
\hline
\end{tabular}

\section{Notes:}

Columns (1) and (2) are based on OECD data as described in the main text and normalized so that the real value of GDP across countries equals the nominal value of GDP in US\$. These are also reported in Table 1.

Columns (3) and (4) are alternative expenditure price levels based on PWT 6.1 data, and have the same normalization as columns (1) and (2). 